\title{
Emerging intravesical therapies for management of nonmuscle invasive bladder cancer
}

This article was published in the following Dove Press journal:

Open Access Journal of Urology

18 May 2010

Number of times this article has been viewed

\section{Jeffrey J Tomaszewski Marc C Smaldone}

Department of Urology, University of Pittsburgh School of Medicine,

Pennsylvania, USA
Correspondence: Marc C Smaldone Department of Urology, University of Pittsburgh School of Medicine, Suite 700, 347I Fifth Avenue, Pittsburgh, PA 15213, USA

Tel + I 4I26924I00

Fax +14126924101

Emailsmaldonemc@upmc.edu

\begin{abstract}
Transitional cell carcinoma (TCC) is the second most common urologic malignancy, and $70 \%$ of patients present with superficial or nonmuscle invasive bladder cancer (NMIBC). Intravesical bacillus Calmette-Guerin (BCG) is the most effective agent for preventing disease recurrence, and the only therapy able to inhibit disease progression. However, recurrence rates as high as $30 \%$ and significant local and systemic toxicity have led to increased interest in alternative intravesical therapies. In patients refractory or intolerant to BCG, BCG-interferon $\alpha 2 b$, gemcitabine, and anthracyclines (doxorubicin, epirubicin, valrubicin) have demonstrated durable clinical responses. Phase I trials investigating alternative cytotoxic agents, such as apaziquone, taxanes (docetaxel, paclitaxel), and suramin are reporting promising data. Novel immunomodulating agents have demonstrated promise as efficacious alternatives in patients refractory to BCG. Optimization of existing chemotherapeutic regimens using hyperthermia, photodynamic therapy, magnetically-targeted carriers, and liposomes remains an area of active investigation. Despite enthusiasm for new intravesical agents, radical cystectomy remains the treatment of choice for patients with NMIBC who have failed intravesical therapy and selected patients with naïve $\mathrm{T} 1$ tumors and aggressive features. This report provides a comprehensive review of contemporary intravesical therapy for NMIBC and refractory NMIBC, with an emphasis on emerging agents and novel treatment modalities.
\end{abstract}

Keywords: transitional cell carcinoma, nonmuscle, invasive, intravesical therapy, BCG

\section{Introduction}

Bladder cancer is the fourth most common malignancy among men in the Western world. ${ }^{1}$ More than $90 \%$ of bladder cancer diagnoses are made in patients older than 55 years of age, with a three-to-one male to female predominance. ${ }^{2}$ Transitional cell carcinomas (TCC) predominate, with superficial or nonmuscle invasive bladder cancers (NMIBC) found at diagnosis in more than $70 \% .^{3}$

Transurethral resection (TUR) facilitates accurate tumor grading and staging, provides local disease control, and is typically performed for the management of newly diagnosed TCC. Following TUR alone, TCC recurs or progresses in $50 \%-80 \%$ and $14 \%$, respectively, despite adequate resection. ${ }^{4}$ The risk of disease recurrence and progression is highly variable, and risk-stratification based on pathologic and clinical variables is commonly utilized for more accurate prediction. ${ }^{5}$

The perioperative instillation of chemotherapy immediately following TUR has been advocated to destroy residual microscopic tumor cells and to prevent re-implantation. ${ }^{6}$ Intravesical therapy has also been employed in an induction and/or maintenance fashion to provide long-term immuno-stimulation of chemotoxicity in submit your manuscript | www.dovepress.com

Dovepress

7237 
an effort to prevent disease recurrence. ${ }^{7}$ The high rate of tumor recurrence in patients with NMIBC mandates lifetime surveillance and leads to high health care related costs despite the use of adjuvant intravesical therapy. ${ }^{8}$ We review intravesical treatment strategies, discuss modes of efficacy enhancement, and explore the role of novel agents in the management of NMIBC.

\section{Immunomodulators}

Immunotherapeutic strategies produce antitumor effects via either passive or active immunity. ${ }^{9}$ Enhancing active immunity, ie, recruitment and imprinting of the host immune system to recognize and effectively destroy tumor cells, is the focus of most of the current work in bladder cancer immunotherapy. Interleukins (ILs), which contribute to the host immune response by stimulating T-cell and natural killer (NK) cell proliferation and cytokine production, have been shown to have antitumor activity in animal models, ${ }^{10}$ and investigators were hopeful that adjunctive IL therapy would improve the efficacy of traditional intravesical agents. ${ }^{9}$ However, initial trials utilizing IL-2, ${ }^{11}$ IL-12, ${ }^{12}$ tumor necrosis factor (TNF), ${ }^{13}$ and granulocyte macrophage colony stimulating factor (GM-CSF) ${ }^{14}$ demonstrated poor evidence of tumor response, local and systemic side effects, and early disease recurrence.

\section{Bacillus Calmette-Guerin}

$\mathrm{BCG}$, an attenuated mycobacterium developed as a vaccine for tuberculosis, has been shown to have significant antitumor activity against many different malignancies. ${ }^{6}$ First described by Morales for the treatment of superficial bladder cancer nearly 20 years ago, ${ }^{13}$ its use in the treatment of NMIBC has gained widespread acceptance in the urologic community. The action of BCG is based on inducing cytokine release in the urine and bladder wall, resulting in the chemoattraction of granulocytes and mononuclear cells. Although the exact mechanism of action is debatable, the initial step appears to be the binding of fibronectin, facilitating attachment to the urothelium and subsequent incorporation of glycoproteins into the bladder wall. The resulting nonspecific immune stimulation leads to release of macrophages, T-lymphocytes, B-lymphocytes, NK cells, and various cytokines. Cytokine release (interferon- $\gamma$, IL-2, and TNF) induces a $\mathrm{TH}_{1}$-mediated response and antitumor activity. 6,15

Intravesical administration of BCG as induction therapy for NMIBC has been shown to delay the time to first recurrence compared with TUR alone. ${ }^{6}$ Shelley et al reviewed six randomized trials comparing TUR alone versus TUR-BCG in patients with $\mathrm{Ta}$ and $\mathrm{T} 1$ bladder cancer. Using tumor recurrence as their outcome of interest, their analysis revealed a significant advantage in patients treated with BCG following TUR over TUR alone. ${ }^{16}$ A recent meta-analysis of 24 randomized clinical trials including nearly 5000 patients with carcinoma in situ (CIS), Ta, or T1 TCC reported that $\mathrm{BCG}$ reduced the odds of disease progression by $27 \%$ compared with TUR alone or resection and another treatment other than BCG. Of importance, these benefits were only seen in patients receiving maintenance therapy and there was no effect on overall or disease-specific survival. ${ }^{6,17}$

Induction treatment regimens of BCG typically begin two to four weeks following resection and are most commonly administered weekly for six weeks. However, there is debate as to the optimal dosing schedule, and controversy persists regarding the role of maintenance therapy and its long-term effect on recurrence and progression. ${ }^{18}$ In a randomized, prospective trial, 550 patients with NMIBC or CIS were randomized to a maintenance therapy arm or no maintenance therapy following a six-week induction course of BCG. Findings demonstrated a significant difference in median recurrence-free survival in the maintenance therapy arm (76.9 versus 35.7 months, $P<0.0001)$ and a $5 \%$ improvement in five-year overall survival $(P=0.08)$ with a median follow-up of 120 months. ${ }^{19}$ Initial reports from large meta-analyses suggest that maintenance therapy should be administered, but the optimal schedule and duration of therapy remains undetermined. , $7,17,20^{-1}$

The use of BCG can be limited by its side effect profile and subsequent intolerance that occurs in approximately $20 \%$ of patients during maintenance therapy. ${ }^{21}$ BCG toxicity includes local and systemic reactions, ranging from cystitis, hematuria, bladder contracture, and mild flu-like symptoms, to life-threatening sepsis. ${ }^{22}$ However, findings of recent large meta-analyses suggest that while the toxicity with BCG is higher than with intravesical chemotherapy, systemic effects do not predict efficacy, ${ }^{23}$ and there is no difference in toxicity between induction and maintenance regimens. ${ }^{24,25}$ Some recent trials have demonstrated that a reduced regimen (one-third dose) may be as effective as standard dosing with fewer side effects. ${ }^{26,27}$

Concern regarding BCG-related toxicity and disease progression has led to the study of other intravesical chemotherapeutic agents (Table 1) in the treatment of NMIBC, most notably mitomycin C (MMC). ${ }^{9}$ However, large meta-analyses examining patients with Ta and T1 TCC have concluded that BCG is superior to intravesical chemotherapy in preventing tumor recurrence in patients at high risk $^{28,29}$ 
Table I Emerging immunomodulating and cytotoxic intravesical agents currently under investigation

\begin{tabular}{|c|c|c|c|c|}
\hline Agent & Mechanism & Advantages & Disadvantages & Toxicity \\
\hline \multicolumn{5}{|c|}{ Immunomodulating agents } \\
\hline IFN (+ BCG) & $\begin{array}{l}\text { T-Helper Type I cell } \\
\text { and NK cell stimulation, } \\
\text { MHC I antigen } \\
\text { expression }\end{array}$ & $\begin{array}{l}\text { a) increased efficacy } \\
\text { b) salvage therapy } \\
\text { c) efficacy not affected } \\
\text { by prior BCG } \\
\text { exposure }\end{array}$ & $\begin{array}{l}\text { a) costly } \\
\text { b) loss of prognostic } \\
\text { information provided by } \\
\text { response to BCG } \\
\text { monotherapy }\end{array}$ & $\begin{array}{l}\text { mild to moderate local adverse } \\
\text { effects }\end{array}$ \\
\hline Bropirimine & $\begin{array}{l}\text { Aryl pyrimidine that } \\
\text { augments endogenous } \\
\text { IFN production }\end{array}$ & $\begin{array}{l}\text { a) powerful antitumor } \\
\text { properties }\end{array}$ & $\begin{array}{l}\text { a) significant hematologic } \\
\text { and systemic toxicity }\end{array}$ & cardiac effects* \\
\hline $\begin{array}{l}\text { Keyhole-Limpet } \\
\text { hemocyanin }\end{array}$ & $\begin{array}{l}\text { Nonspecific immune } \\
\text { stimulator }\end{array}$ & $\begin{array}{l}\text { a) lacks toxicity } \\
\text { b) greater efficacy } \\
\text { than MMC } \\
\text { c) minimal side effects }\end{array}$ & $\begin{array}{l}\text { a) unclear protection } \\
\text { against disease } \\
\text { progression } \\
\text { b) optimal dosing not defined }\end{array}$ & safe and well tolerated \\
\hline $\begin{array}{l}\text { Mycobacterial cell } \\
\text { wall complexes }\end{array}$ & $\begin{array}{l}\text { Nonspecific immune } \\
\text { stimulator } \\
\text { Induction of apoptosis }\end{array}$ & $\begin{array}{l}\text { a) eplicates efficacy of } \\
\text { BCG without the } \\
\text { side effects }\end{array}$ & a) side effects ill-defined & $\begin{array}{l}\text { mild to moderate local adverse } \\
\text { effects }\end{array}$ \\
\hline Mistletoe lectin & $\begin{array}{l}\text { Induces cytokine release, } \\
\text { increases lymphocyte } \\
\text { activation marker } \\
\text { expression }\end{array}$ & a) safe & $\begin{array}{l}\text { a) clinical efficacy not yet } \\
\text { defined }\end{array}$ & safe and well tolerated \\
\hline \multicolumn{5}{|c|}{ Chemotherapeutic agents } \\
\hline Gemcitabine & $\begin{array}{l}\text { Pyrimidine analog that } \\
\text { inhibits cell growth } \\
\text { and induces } \\
\text { apoptosis }\end{array}$ & $\begin{array}{l}\text { a) salvage therapy } \\
\text { b) minimal systemic } \\
\text { absorption and } \\
\text { toxicity } \\
\text { c) prophylactic efficacy }\end{array}$ & $\begin{array}{l}\text { a) myelosuppression } \\
\text { b) anemia }\end{array}$ & $\begin{array}{l}\text { mild to moderate local adverse } \\
\text { effects }\end{array}$ \\
\hline Anthracyclines & $\begin{array}{l}\text { Topoisomerase II } \\
\text { inhibitor }\end{array}$ & $\begin{array}{l}\text { a) increased efficacy } \\
\text { b) inexpensive } \\
\text { c) safe }\end{array}$ & $\begin{array}{l}\text { Efficacy of maintenance } \\
\text { therapy unknown }\end{array}$ & $\begin{array}{l}\text { mild to moderate local adverse } \\
\text { effects }^{\dagger}\end{array}$ \\
\hline Apaziquone & Alkylating agent & $\begin{array}{l}\text { a) not cell-cycle } \\
\text { specific }\end{array}$ & $\begin{array}{l}\text { a) frequent side effects } \\
\text { (leukopenia, irritative } \\
\text { voiding symptoms) }\end{array}$ & $\begin{array}{l}\text { mild to moderate local adverse } \\
\text { effects }\end{array}$ \\
\hline Taxanes & $\begin{array}{l}\text { Microtubule } \\
\text { polymerization } \\
\text { inhibitor }\end{array}$ & $\begin{array}{l}\text { a) no systemic } \\
\text { absorption } \\
\text { b) limited toxicity }\end{array}$ & $\begin{array}{l}\text { a) poor aqueous solubility } \\
\text { b) limited clinical experience }\end{array}$ & $\begin{array}{l}\text { mild to moderate local adverse } \\
\text { effects }\end{array}$ \\
\hline Suramin & VEGF antagonist & $\begin{array}{l}\text { a) limited local and } \\
\text { systemic toxicity }\end{array}$ & a) limited clinical experience & $\begin{array}{l}\text { metabolic, hematologic, renal } \\
\text { and neurologic sequelae } \\
\text { (systemic administration); } \\
\text { minimal effects with } \\
\text { intravesical adminstration }\end{array}$ \\
\hline
\end{tabular}

Abbreviations: Ab, antibody; NK, natural killer; MHC, major histocompatability complex; VEGF, vascular endothelial growth factor.

*Discontinued by manufacturer in 1996 due to cardiac toxicity; ${ }^{\dagger}$ Synthetic derivatives epirubicin and valrubicin show improved local toxicity profiles.

and when maintenance therapy is utilized. ${ }^{17,30}$ Sylvester et al reviewed nine randomized trials including 700 patients with CIS treated with either BCG or intravesical chemotherapy (MMC, epirubicin, adriamycin, or combination therapy). With a median follow-up of 3.6 years, the researchers concluded that intravesical BCG significantly reduces the risk of short- and long-term treatment failure compared with intravesical chemotherapy and that BCG is first-line therapy for treatment of CIS. ${ }^{31}$ Further review of these analyses has led to the current American Urological Association (AUA) consensus that an induction course of BCG followed by maintenance therapy is recommended for the treatment of high-grade Ta or T1 TCC and CIS. ${ }^{6,7,9}$

Although currently first-line therapy for high-risk NMIBC, five-year recurrence rates are estimated to be $34 \%$ in patients receiving $\mathrm{BCG}$ maintenance therapy. ${ }^{7}$ The efficacy of BCG is also hampered by side effects and treatment intolerance, as well as the risks of understaging or progression to muscle-invasive disease. Radical cystoprostatectomy and urinary diversion is currently the standard of care for muscleinvasive TCC, ${ }^{32}$ and there is growing consensus that relative indications for early cystectomy include recurrent NMIBC 
refractory to intravesical therapy and naïve $\mathrm{T} 1$ disease with high-risk features for tumor progression. ${ }^{33}$ However, the risk of perioperative complications and morbidity associated with cystectomy has spawned further interest in the utility of novel intravesical agents for BCG refractory disease. ${ }^{6}$

\section{Interferon}

Interferon (IFN) $\alpha 2 \mathrm{~b}$ has been utilized as both monotherapy and adjunct therapy in BCG-refractory patients. ${ }^{69}$ IFNs are glycoproteins that mediate the host immune response in a dose-dependent manner by increasing antibody responsiveness, stimulating NK cells, and inducing expression of Class I major histocompatibility complex antigens. ${ }^{9,34}$ The results of early investigations of IFN as monotherapy to prevent disease recurrence have been disappointing, demonstrating no benefit or inferior recurrence rates when compared with placebo controls ${ }^{35}$ or other intravesical agents (BCG, MMC, MMC-IFN). ${ }^{6,36}$

In contrast, results from initial trials investigating the combination of IFN-BCG have been more promising. ${ }^{6}$ O'Donnell et al reviewed their experience utilizing BCG plus 50 million units of IFN in 40 patients who had relapsed following induction BCG therapy. ${ }^{9}$ With a mean follow-up of 30 months, $63 \%$ and $53 \%$ recurred at one and two years, respectively. ${ }^{37}$ In a multicenter Phase II trial, BCG-IFN was administered to 536 BCG-naïve patients and 467 BCGrefractory patients with NMIBC. With a median follow-up of 24 months, recurrence-free rates were $59 \%$ and $45 \%$ in the BCG-naïve and BCG-refractory groups, respectively. ${ }^{6}$ Factors associated with tumor recurrence were tumor size $>5 \mathrm{~cm}$, prior BCG failure, and tumor multifocality. ${ }^{38}$ In a recent subanalysis of the same cohort, Gallagher et al reported that BCG-refractory patients who relapsed more than one year following induction therapy had similar response rates to those of BCG-naïve patients. ${ }^{6}$ However, recurrence rates were higher in those with recurrent disease less than one year following induction therapy. ${ }^{39}$ The use of BCG-IFN as initial therapy is limited and currently there is no consensus regarding the benefit of the addition of IFN in BCG-naïve patients. ${ }^{40}$ Based on the available data, BCG-IFN appears to be a well-tolerated alternative to salvage therapy in selected patients with BCG-refractory NMIBC, but radical treatment options should be pursued for early failures and true BCG-refractory disease. ${ }^{9}$

\section{Emerging agents under investigation}

Bropirimine is a broad-spectrum immunostimulatory compound with oral absorption and urinary excretion. ${ }^{6}$
Although not currently available in the US, the findings of a recent clinical trial demonstrated equivalent response rates to BCG in 55 BCG-naïve patients with CIS. ${ }^{41}$ The results of a Phase II trial examining the utility of bropirimine in 86 BCG-refractory patients reported a complete response in $24 \%$ of patients, with a $6 \%$ rate of progression to muscleinvasive disease or metastasis. ${ }^{42}$ However, a recent Southwest Oncology Group Phase II trial investigating combination bropirimine-BCG therapy in 51 BCG-naïve patients with CIS reported discouraging five-year progression-free (53\%) and overall survival $(80 \%)$ rates, and recommended that no further evaluation of this combination be conducted. ${ }^{43}$ Bropirimine was discontinued by the manufacturer in 1996 due to significant concerns regarding cardiac toxicity and is currently not under clinical investigation in NMIBC. ${ }^{9}$

Keyhole limpet hemocyanin (KLH) is a highly antigenic respiratory pigment of the mollusk Megathura cranulata that results in nonspecific immune stimulation. ${ }^{44}$ Attractive as an alternative to BCG due to its limited side effect profile, there have been several small Phase I and II clinical trials investigating its use as an intravesical agent. ${ }^{9}$ Jurincic-Winkler et al treated 13 Tis patients with six weeks of KLH induction monotherapy, monthly treatments for one year, and bimonthly treatments for the two following years, reporting two complete responses at 66 and 82 months. ${ }^{9.45}$ However, patients not responding to two KLH treatments were managed with BCG, and most patients exhibited disease progression regardless of therapy. In a multicenter study, Lamm et al reported a durable response in 64 patients with Tis $(50 \%)$ and residual Ta-T1 disease (20\%) treated with escalating doses of $\mathrm{KLH}$ for six weeks. ${ }^{46}$ Despite promising results, comparative studies with BCG and chemotherapeutic agents (MMC, ethoglucid) have not demonstrated a benefit with $\mathrm{KLH}$ in patients with refractory NMIBC, ${ }^{47,48}$ and further investigation is necessary before $\mathrm{KLH}$ can be recommended in patients refractory or intolerant to BCG. ${ }^{9}$

As a live bacterium, BCG carries the potential for significant adverse effects of varying clinical severity. In an effort to minimize these reactions, researchers have investigated using reduced dosages, adjunctive antibiotics, or heat/radiation-inactivated bacteria, with minimal success. ${ }^{9,49}$ However, recent work investigating the use of Mycobacterium phlei mycobacterial cell wall complexes (MCC) containing mycobacterial DNA has generated significant interest. ${ }^{9}$ A dual mechanism of action has been postulated, with both immunomodulatory (similar to BCG) as well as chemotherapeutic apoptotic features. ${ }^{50}$ Early clinical work utilizing an MCC emulsion in 61 patients 
with Tis over a 48-week duration demonstrated a partial or complete response rate in 52\% of BCG-refractory patients and $69 \%$ of BCG-naïve patients with acceptable side effects. ${ }^{51}$ Subsequent work has resulted in a new product formulation which still contains mycobacterial DNA but without the toxic preservative thimerosal. ${ }^{49}$ This formulation is currently being investigated in 55 patients with CIS (30\% had additional papillary tumors), 25 of whom received $4 \mathrm{mg}$ MCC per treatment, and 30 received $8 \mathrm{mg}$ MCC per treatment on similar schedules. Early results demonstrate an encouraging initial complete response rate $(27 \%-46 \%)$ at weeks 12 and 26 in both treatment groups, whereas response rates were more marginal at 18 months follow-up $(23 \%-32 \%)$ and were comparable between BCG-refractory and BCG-naïve patients. ${ }^{52}$ Based on these early promising results, patients are currently being enrolled for clinical trials examining the efficacy of MCC in high-grade nonmuscle invasive lesions refractory to $\mathrm{BCG}$ as well as in BCG-naïve patients at high risk for recurrence or progression. ${ }^{49}$

A recombinant form of mistletoe lectin, another potential immunotherapeutic agent, is currently under development. By stimulating the release of cytokines and expression of lymphocyte activation markers, mistletoe lectin has been shown to inhibit urothelial carcinogenesis in rat models. ${ }^{53}$ In the first clinical application, Goebell et al randomized 45 patients with pTa G1-2 TCC to a single adjuvant mistletoe lectin treatment two weeks following TUR versus no adjuvant therapy. At 18 months' follow-up, there were no significant differences with respect to recurrence-free interval or the number of recurrences between groups. ${ }^{54}$ However, in a subsequent Phase II study examining use of mistletoe lectin induction therapy in 30 patients with NMIBC, Elsasser-Beile et al reported no local or systemic side effects and a 33\% recurrence rate at 12 months, which was comparable with findings in an historical control group of patients undergoing BCG induction therapy. While further investigation is warranted to determine the optimal dose and timing of treatment, mistletoe lectin may ultimately prove to be a better tolerated alternative to $\mathrm{BCG}$ in selected patients. ${ }^{55}$

\section{Gene therapy}

Gene therapy has several theoretical advantages over conventional intravesical therapies, including a high selectivity for tumor cells with mutated genes, potential to restore normal cell growth by correcting genetic defects, and potential to reduce chemoresistance. ${ }^{6,56}$ Gene delivery systems include both viral (adenovirus, vaccinia) and nonviral vectors (lipoplexes, Table 2). While the relative advantages/disadvantages of each method of gene delivery is beyond the scope of this review, the inadvertent systemic absorption of viral vectors resulting in an excessive immune response is a significant concern that may be avoidable with the utilization of intravesical or nonviral vectors. ${ }^{6,57}$ Viral receptor expression and physical composition of urothelial surface cells are formidable barriers to the delivery of intravesical gene therapy. Current research efforts have been directed at modulating coxsackie-adenovirus receptor expression, ${ }^{58}$ as well as coadministration of the polyamide syn3 to disrupt the urothelial barrier, ${ }^{59}$ thereby increasing viral uptake and improving adenoviral therapy efficacy. Use of replication-competent viral systems is also being explored in animal models, but concerns include infection of nontargeted cells and the potential for carcinogenic insertional mutagenesis. ${ }^{56}$

Early in vivo and in vitro studies have shown promising results. Using a rat model, Conner et al demonstrated the efficacy of adenoviral-mediated gene-delivered IFN therapy to inhibit bladder cancer growth, with increased drug concentrations and retention times compared with standard intravesical instillation. ${ }^{60}$ Utilizing a replication-competent oncolytic adenovirus (CG0070) encoding GM-CSF, Ramesh et al demonstrated selective replication, cytotoxicity, GM-CSF production, and antitumor efficacy in both in vitro and in vivo bladder TCC models compared with normal human cells. ${ }^{61}$ Recombinant vaccinia virus delivery of a p53 gene in an orthotopic mouse bladder tumor model provided a survival advantage compared with phosphate buffer or empty vector control groups. ${ }^{62}$ In a murine bladder tumor model, Lee et al examined the efficacy of recombinant BCG and murine IL-12 DNA vaccines using eukaryotic expression vectors. ${ }^{6}$ The cumulative survival of mice treated with both the BCG vaccine and the IL-12 vaccine was significantly higher compared with that of controls or those treated with either vaccine alone. ${ }^{63}$ Horinaga et al administered intravesical IL-12 gene therapy delivered in cationic liposome vector in a mouse model with orthotopic bladder tumors. ${ }^{6}$ When compared with a high-dose BCG-treated group and negative controls, IL-12 therapy was equivalent to BCG, and both treatments were superior to the reporter gene-negative controls. ${ }^{6}$ Interestingly, surviving IL-12-treated mice rechallenged with additional tumor cell implantation after 60 days survived significantly longer than BCG-treated mice, suggesting a more durable tumoricidal effect. ${ }^{64}$

Early Phase I clinical trials have demonstrated that intravesical gene therapy can be safely administered in bladder cancer patients with minimal toxicity. In four patients with muscle invasive bladder cancer, Gomella et al administered 
Table 2 Investigational genetic therapies for the management of NMIBC

\begin{tabular}{|c|c|c|c|}
\hline Agent & Mechanism & Advantages & Disadvantages \\
\hline \multicolumn{4}{|l|}{ Gene therapy } \\
\hline \multicolumn{4}{|l|}{ Vectors } \\
\hline Adenovirus & $\begin{array}{l}\text { Cell entry via the } \\
\text { coxsackie/adenovirus } \\
\text { membrane receptor }\end{array}$ & $\begin{array}{l}\text { a) DNA does not integrate into } \\
\text { host chromosomes } \\
\text { b) ease of obtaining recombinant } \\
\text { proteins and producing vectors } \\
\text { in high titers } \\
\text { c) high viability of host cells } \\
\text { post-infection }\end{array}$ & $\begin{array}{l}\text { a) poor viral uptake } \\
\text { b) inadvertent systemic absorption } \\
\text { may elicit excessive immune } \\
\text { response or insertional } \\
\text { mutagenesis in host cells }\end{array}$ \\
\hline Vaccinia & $\begin{array}{l}\text { Recombinant double-stranded } \\
\text { DNA virus }\end{array}$ & $\begin{array}{l}\text { a) broad applicability } \\
\text { b) rapid infection } \\
\text { c) efficient transgene } \\
\text { expression }\end{array}$ & $\begin{array}{l}\text { a) vaccination against small pox } \\
\text { may inhibit gene transfer }\end{array}$ \\
\hline Nonviral (lipoplexes) & lonic cellular uptake & $\begin{array}{l}\text { a) simple preparation } \\
\text { b) inexpensive } \\
\text { c) low immunogenicity } \\
\text { d) carry larger genes }\end{array}$ & a) poor cell uptake and transfer \\
\hline $\begin{array}{l}\text { Monoclonal antibodies } \\
\text { (Thrombospondin-I, EGF receptor) }\end{array}$ & $\begin{array}{l}\text { Reduce tumor angiogenesis } \\
\text { and induce apoptosis }\end{array}$ & $\begin{array}{l}\text { a) simple preparation } \\
\text { b) highly specific } \\
\text { c) low immunogenicity }\end{array}$ & a) Lack of adequate delivery vehicle \\
\hline $\begin{array}{l}\text { Hemagglutinating virus of Japan } \\
\text { envelope factor (HVJ-E) } \\
\text { siRNA }\end{array}$ & $\begin{array}{l}\text { Induces extensive immunologic } \\
\text { antitumor activity } \\
\text { Silences targeted gene } \\
\text { expression on the } \\
\text { mRNA level }\end{array}$ & $\begin{array}{l}\text { a) no need for concurrent } \\
\text { chemotherapy administration } \\
\text { a) specificity } \\
\text { b) high efficiency }\end{array}$ & $\begin{array}{l}\text { a) investigational } \\
\text { b) poor specificity } \\
\text { a) insertional mutagenesis } \\
\text { b) iatrogenic leukemia } \\
\text { c) inefficient cellular uptake and } \\
\text { local delivery }\end{array}$ \\
\hline \multicolumn{4}{|l|}{ Therapeutic targets } \\
\hline p53 & $\begin{array}{l}\text { Dysregulation of apoptosis; } \\
\text { direct lytic effect }\end{array}$ & & \\
\hline IFN- $\alpha$ & $\begin{array}{l}\text { Inhibits tumor proliferation; } \\
\text { induces differentiation }\end{array}$ & & \\
\hline IL-10 & Suppresses APC capacity & & \\
\hline CG0070 & $\begin{array}{l}\text { Preferential GM-CSF } \\
\text { production activates host immune } \\
\text { response }\end{array}$ & & \\
\hline
\end{tabular}

Abbreviations: NMIBC, nonmuscle invasive bladder cancer; INF $\alpha$, interferon alpha; APC, antigen presenting cell; IL, interleukin; GM-CSF, granulocyte macrophage colony stimulating factor; EGF, epidermal growth factor.

three increasing doses of intravesical DryVax (Wyeth-Ayerst Laboratories, Philadelphia, PA), a DNA poxvirus, prior to cystectomy. ${ }^{65}$ Histologic examination of the bladders 24 hours following the last dosing revealed evidence of viral infection in both tumor and normal cells, and a significant mucosal and submucosal inflammatory reaction in both tumor and normal tissue. ${ }^{6}$ There were no clinical or laboratory manifestations of vaccinia-related toxicity with the exception of mild dysuria. In patients with histologically confirmed TCC, Kuball et al administered an intratumoral injection or intravesical instillation of an adenoviral vector containing wild-type p53 with a gene transfer enhancer ( $\mathrm{SCH} 58500$ ) in 11 patients prior to cystectomy. Specific transgene expression was detected in tumors and normal bladder samples in $7 / 8$ patients treated intravesically, but was not seen in patients receiving intratumoral injection. No cases of dose-limiting toxicity were observed and side effects were transient. ${ }^{6,66}$ In a feasibility study, Pagliaro et al administered repeated doses of adenoviral vector-mediated p53 (Ad5CMV-p53) to 13 patients with locally advanced TCC who were not candidates for cystectomy. The treatment was well tolerated by all patients and specific transgene expression was found in $2 / 7$ patients. ${ }^{67}$ Emerging therapies currently being investigated include gene therapy using viral and nonviral vectors for transfer, monoclonal antibodies, and direct tumoricidal viruses. While there is currently little evidence demonstrating a clinical benefit in human studies, gene therapy remains an exciting field for future investigation, and the further development of alternative vector systems will help define a therapeutic role in the management of NMIBC. 


\section{Chemotherapeutic agents}

The use of intravesical chemotherapeutic agents for NMIBC has been met with variable success. ${ }^{6}{ }^{6}$ Traditionally reserved for use in patients with BCG-refractory disease, multiple agents, most commonly MMC, epirubicin, and valrubicin, are currently being investigated as primary and secondary therapy for NMIBC. ${ }^{6}$ Early data suggested that the addition of intravesical chemotherapy to TUR yields a $14 \%$ reduction of tumor recurrence but has limited benefit with respect to disease progression. ${ }^{69}$ However, in two recent meta-analyses examining the impact of multiple intravesical chemotherapeutic agents on recurrence prevention, Huncharek reported that recurrence rates may be reduced by as much as $70 \%$ when compared with TUR alone. ${ }^{6}$ Variations in dosage and treatment schedules were postulated to account for the large differences in recurrence rates observed across studies..$^{70,71}$ Current efforts are focused on defining the ideal treatment schedule, optimizing the efficacy of traditionally utilized therapies, and investigating novel chemotherapeutic agents.

\section{Mitomycin C}

MMC is a cross-linking agent that inhibits DNA synthesis. ${ }^{72}$ Due to its high molecular weight ( $329 \mathrm{kDa})$, there is reduced risk of transurothelial absorption and side effects are minimal even in the immediate postoperative period. ${ }^{9,73}$ Currently, the dosage varies from 20 to $60 \mathrm{mg}$ per instillation. ${ }^{6}$ The most commonly used dose is $40 \mathrm{mg}$ in $40 \mathrm{~mL}$ of saline or sterile water administered weekly for eight weeks followed by monthly instillations for one year. ${ }^{7}$ Initial studies investigating the use of MMC as monotherapy for NMIBC following TUR showed promising results. ${ }^{74,75}$ In a small prospective trial, Huland et al randomized 58 patients with NMIBC following TUR to either no further therapy or MMC at $20 \mathrm{mg} / 20 \mathrm{~mL}$ instilled every two weeks for the first year and every four weeks for the second year. Although patients with superficial low-grade tumors were probably included, recurrence rates with MMC (7\%) were significantly lower compared with the control group (50\%). ${ }^{76}$ Tolley et al randomized 502 patients following TUR to no adjuvant treatment, one perioperative instillation of $\mathrm{MMC}$, and up to five MMC instillations at three-month intervals following resection. With a median follow-up of five years, the authors reported decreased recurrence rates and an increased recurrence-free interval in patients undergoing MMC therapy, with evidence to suggest a slight advantage of multiple instillations over one perioperative instillation. ${ }^{6,77}$

Significant attention is currently being directed towards defining the optimal MMC treatment schedule, and identifying which patients will benefit from a single perioperative treatment compared with chronic maintenance therapy. ${ }^{6}$ Chemotherapeutic agents are preferred to BCG in the immediate perioperative period due to reduced risks of systemic absorption following TUR. Tolley et al reported a significant decrease in tumor-recurrence risk in patients with NMIBC treated with a perioperative (less than 24 hours following TUR) $40 \mathrm{mg}$ MMC treatment compared with TUR alone. ${ }^{77}$ Benefits of a single immediate instillation on the risk of tumor recurrence have been reported with epirubicin ${ }^{78}$ and doxorubicin ${ }^{79}$ as well, although optimal timing post-TUR has not been determined. In a meta-analysis of seven randomized trials comparing TUR alone with TUR plus one immediate instillation of chemotherapy, Sylvester et al reported a 39\% reduction in risk of recurrence (odds ratio [OR] 0.61, $P<0.0001$ ). Benefits were seen in patients with a single tumor or with multiple tumors. However, recurrence was higher in patients with multiple tumors compared with solitary tumors $(65.2 \%$ versus $35.8 \%){ }^{80}$ Based on these data, the current AUA superficial bladder cancer guidelines recommend that a single dose of intravesical chemotherapy be administered immediately postoperatively (less than six hours) in patients with small volume solitary tumors when there is no evidence of bladder perforation. ${ }^{7}$ Currently consensus is lacking regarding effectiveness of perioperative MMC on decreasing recurrence rates compared with other chemotherapeutic agents. ${ }^{6}$

In patients with intermediate- and high-risk NMIBC, induction therapy is recommended to prevent disease recurrence. ${ }^{7}$ The literature currently supports the superiority of BCG in limiting disease recurrence and progression compared with chemotherapeutic agents. ${ }^{31}$ However, BCG toxicity limits its use in a significant number of patients, resulting in an increasing need for alternative therapies. In a meta-analysis of six trials comparing BCG and MMC in 1527 patients, Shelley et al reported a reduced incidence of local (30\% versus $44 \%$ ) and systemic toxicities (12\% versus $19 \%$ ) with MMC, with no significant difference in recurrence, progression, or survival. While the overall analysis, which included low-risk patients, failed to show a difference in risk of recurrence, a subgroup analysis of three trials including only patients with high-risk NMIBC revealed a $31 \%$ reduced risk of tumor recurrence with BCG compared with MMC. ${ }^{6,28,29}$ Additional meta-analyses have demonstrated that maintenance $\mathrm{BCG}$ is required to see the greatest benefit in reducing tumor recurrence and progression when compared with MMC. ${ }^{6,24,30}$ 
Until recently, there was general consensus that chemotherapy was effective in reducing short-term risk for recurrence but its efficacy was only marginal in the long term. ${ }^{79,81,82}$ However, in a recent prospective trial, Friedrich et al randomized 495 patients with intermediate- to high-risk NMIBC following TUR to a six-week course of BCG, a six-week course of MMC, or a six-week course of MMC followed by monthly instillations for three years. Three-year recurrence-free rates were $65.5 \%$ for short-term BCG, $68.6 \%$ for short-term MMC, and $86.1 \%$ for patients undergoing long-term MMC therapy, ${ }^{83}$ supporting the potential use of MMC maintenance therapy as an alternative to BCG in high-risk populations. Current efforts are being directed towards optimizing the efficacy of chemotherapeutic agents and will be discussed later in this review. ${ }^{9}$

\section{Thiotepa}

Thiotepa, an alkylating agent that inhibits nucleic acid synthesis by inducing the cross-linkage of DNA, RNA, and proteins,${ }^{84}$ is currently the only chemotherapeutic agent approved by the Food and Drug Administration for papillary TCC. ${ }^{6}$ Dosing ranges from $30 \mathrm{mg}$ in $30 \mathrm{~mL}$ to $60 \mathrm{mg}$ in $60 \mathrm{~mL}$ sterile water or saline, with six- to eight-weekly instillations followed by administration monthly for one year. ${ }^{6}$ Risks of local toxicity such as irritating voiding symptoms are prevalent, and there is a significant risk of systemic myelosuppresion requiring frequent leukocyte and platelet count monitoring due to the low molecular weight of thiotepa $(189 \mathrm{kDa}) .^{85}$

Initial trials demonstrated the efficacy of thiotepa in preventing recurrence when compared with controls. ${ }^{84,86}$ However, subsequent trials have demonstrated inferior results when thiotepa is compared with $\mathrm{MMC}^{85}$ or BCG. Martinez-Pineiro et al reported the results of a prospective trial in which patients with NMIBC were randomized to 15 courses of intravesical doxorubicin $50 \mathrm{mg}$, thiotepa $50 \mathrm{mg}$, or BCG $150 \mathrm{mg}$ following TUR. ${ }^{87}$ With three years of follow-up, patients randomized to BCG demonstrated a significant reduction in risk of recurrence (13.7\%) when compared with thiotepa (35.7\%) or doxorubicin $(43.4 \%){ }^{6}$ A similar trend was seen when patients were stratified by stage of disease. Review of these initial studies identified nine controlled trials including 1130 patients. Reviewing five of the trials that achieved statistical significance, ${ }^{84,88-91}$ the mean rate of recurrence in the control populations was $61 \%$ versus $49 \%$ in the treated groups, resulting in a modest $12 \%$ benefit with thiotepa therapy. ${ }^{69}$ Currently, due to its marginal efficacy and risk of systemic toxicity, use of thiotepa is limited to patients who cannot tolerate BCG or selected BCG-refractory cases not medically fit for cystectomy. ${ }^{6}$

\section{Gemcitabine}

Gemcitabine is a pyrimidine analog that exhibits antitumor activity by inhibiting cell growth and triggering apoptosis, and is currently a staple in the systemic chemotherapeutic regimens utilized in metastatic and locally advanced TCC. 6,9,92 Phase I trials have reported that the high molecular weight of gemcitabine (299.66 kDa) prevents systemic toxicity with an intact bladder, ${ }^{93}$ and the ablative efficacy of gemcitabine has also been demonstrated in early tumor marker studies. ${ }^{94}$

Phase II clinical trials are currently underway investigating the efficacy of intravesical gemcitabine following TUR for NMIBC. ${ }^{9}$ In 116 patients undergoing weekly dosing for six weeks following TUR, Bartoletti et al reported recurrence rates of $25.9 \%$ and $77.1 \%$ in patients with intermediateand-high risk disease, respectively. ${ }^{95}$ With a novel pre- and post-TUR dosing scheme in nine patients with persistent or recurrent Ta-1, Grade 1-2 TCC following previous intravesical therapy, Mattioli et al reported recurrence in $77.7 \%$ of patients. ${ }^{96}$ Dalbagni et al recently reported their observations in 30 patients who were either refractory or intolerant to BCG and treated with twice-weekly gemcitabine for three weeks. With a median follow-up of 19 months, 50\% achieved a complete response, $40 \%$ relapsed with a median recurrence-free survival of 3.6 months, and $37 \%$ progressed to cystectomy. ${ }^{97}$ A randomized Phase III clinical trial of gemcitabine versus MMC in recurrent bladder cancer revealed $72 \%$ and $61 \%$ disease-free recurrence rates in the gemcitabine and $\mathrm{MMC}$ arms, respectively, at a median follow-up of 36 months. ${ }^{98}$ A recent single-arm prospective trial utilizing gemcitabine in 20 patients with BCG-refractory NMIBC revealed 55\% disease recurrence at a median follow-up of 15.2 months. In this series, the authors reported a mean time to first recurrence of 3.5 months, and $45 \%$ of patients with recurrent disease exhibited disease progression. ${ }^{99}$ While promising as both a primary and adjuvant therapy, further prospective comparisons with contemporary agents are warranted, and at this time gemcitabine is limited to conservative use in selected cases of intravesical treatment failure. ${ }^{6,9}$

\section{Anthracyclines}

Doxorubicin, epirubicin, and valrubicin are anthracycline antibiotics that prevent protein synthesis by binding DNA base pairs and inhibiting topoisomerase II. ${ }^{9,100}$ While side effects including chemical cystitis, decreased bladder capacity, hematuria, and post-instillation fever have hampered the 
use of doxorubicin, the synthetic derivatives epirubicin and valrubicin show similar therapeutic efficacy with better local toxicity profiles. ${ }^{9,101}$ Five early trials randomizing patients to intravesical doxorubicin or TUR alone reported an average recurrence rate of $38 \%$ with doxorubicin compared with 53\% for TUR, with no benefit shown for disease progression. ${ }^{6,9,69}$ Studies comparing epirubicin and valrubicin with TUR alone have reported disease recurrence rates comparable with doxorubicin. ${ }^{78,101}$ Randomized controlled trials have demonstrated that recurrence rates following administration of doxorubicin and epirubicin are inferior to BCG, ${ }^{102,103}$ which has limited anthracycline use in most early studies to immediate postoperative instillation, BCG-refractory disease, and CIS. ${ }^{9}$

Small trials have indicated that a single perioperative dose of epirubicin reduces disease recurrence compared with IFN or TUR alone. ${ }^{104}$ In a small series of patients with NMIBC randomized to perioperative epirubicin, induction epirubicin, or induction MMC with five years of follow-up, Liu et al reported similar recurrence rates and minimal toxicity in the perioperative epirubicin arm, suggesting that a single perioperative dose of epirubicin may be the most efficacious means of preventing TCC recurrence in the short term with minimal adverse effects. ${ }^{9,105}$ However, the superiority of BCG was demonstrated in a recent randomized prospective trial comparing BCG with the combination of epirubicin and IFN $\alpha 2 b$ for the adjuvant treatment of high-grade T1 tumors. Sixty-two percent were disease-free in the combination arm as opposed to $73 \%$ in the BCG arm at 24 months' follow-up, although there were no differences regarding progression and adverse events between groups, and the subgroup analysis showed that the superiority of BCG was mainly in those with concomitant CIS. ${ }^{106}$ Sequential instillation therapy with doxorubicin in combination with MMC has been investigated in a small series. ${ }^{6,9}$ Sekine et al randomized 42 patients with NMIBC to either BCG or doxorubicin with MMC. Initial response rates ( $86 \%$ versus $81 \%$ ) were equal between groups and, with a mean follow-up of 47 months, only five patients developed disease progression. ${ }^{107} \mathrm{~A}$ recent multi-institutional study investigated the use of valrubicin in 90 patients with refractory CIS, $60 \%$ of whom had failed three or more intravesical agents. The findings of this study demonstrated that $21 \%$ of patients had a complete response, $10 \%$ remained disease-free over a follow-up of 10 years, and $56 \%$ progressed to cystectomy. ${ }^{108}$ Based on these data, use of anthracyclines has been widely accepted overseas, demonstrating the most utility in patients with NMIBC and CIS who have failed or are intolerant to BCG therapy. ${ }^{6}$

\section{Apaziquone}

Apaziquone is an indoloquinone bioreductive alkylating agent that results in cell death via the redox cycle and alkylation of DNA. ${ }^{109}$ The relative stability of the compound and rapid pharmacokinetic elimination of the drug make it an intriguing agent for use in NMIBC, and Phase I/II trials have confirmed minimal local and systemic toxicity. ${ }^{9,110,111}$ In a recent update of their Phase I study, Jain et al reported that of the eight patients who achieved a complete response, $50 \%$ relapsed over a median follow-up of 31 months. Of note, the recurrence-free interval significantly increased following apaziquone administration compared with historic recurrence intervals pretreatment. ${ }^{112}$ In the largest clinical experience to date, Van der Heijden et al administered six weekly instillations of $4 \mathrm{mg} / 40 \mathrm{~mL}$ apaziquone to 46 patients with Ta-1, G1-2 NMIBC following TUR. ${ }^{6}$ Two-thirds of subjects demonstrated a complete histologic response rate at 2-4 weeks, with local side effects comparable with those of other chemotherapy instillations. ${ }^{9,113}$ With longer follow-up, of the 31 patients who achieved a complete response, observed recurrence-free rates at one and two years were $56.5 \%$ and $49.5 \%$, respectively. ${ }^{114}$ These initial data support apaziquone's promise as an intravesical agent, and Phase III trials investigating its use during immediate postoperative instillation and post-TUR induction therapy are underway. ${ }^{6}$

\section{Taxanes}

Docetaxel and its close relative, paclitaxel, are from a class of cytotoxic agents (taxoids) that inhibit the polymerization of microtubules by promoting intracellular bundling, resulting in M-phase cell cycle arrest and cell death., ${ }^{9,100}$ The systemic administration of taxanes have resulted in antitumor activity in metastatic bladder cancer, ${ }^{115}$ and recent in vitro studies have demonstrated their efficacy in TCC cytotoxicity assays as well. 9,116 In a Phase I trial of six weekly docetaxel treatments in 18 patients with recurrent NMIBC who had failed at least one intravesical therapy, McKiernan et al reported a complete response rate of $56 \%$ at post-treatment cystoscopy and biopsy, with minimal local toxicity. $6,9,117$ Long-term clinical outcomes in this cohort revealed $22 \%$ and $17 \%$ complete and partial response rates, respectively, while $61 \%$ failed treatment at a median follow-up of 48.3 months. ${ }^{118}$ In a recent update of their series of 33 patients with refractory NMIBC, Barlow et al reported a $61 \%$ complete response rate after six weeks of induction therapy, and one- and two-year recurrence-free survival rates were $45 \%$ and $32 \%$, respectively. ${ }^{119}$ Taxoids are attractive candidates for intravesical therapy due to their potency, high molecular 
weight (853.9-861.9 kDa), and lipophilicity. ${ }^{6}$ However, poor aqueous solubility has previously limited their practicality for intravesical administration. Current studies investigating the feasibility of bioadhesive polymicropheres to optimize paclitaxel release and adhesion to the urothelium in murine models are in progress and will be discussed later in this review. ${ }^{9,120}$

\section{Suramin}

Suramin is a polysulfonated naphthylurea and a potent antagonist of vascular endothelial growth factor (VEGF). ${ }^{109}$ Previous studies have demonstrated that increased VEGF levels in primary superficial tumors or in urine are associated with early recurrence or stage progression, ${ }^{121}$ and identified VEGF as a possible candidate for targeted therapy in NMIBC. ${ }^{9}$ Suramin was shown to inhibit the activity of several angiogenic factors produced by bladder cancer cell lines, as well as cell proliferation, during in vitro studies. ${ }^{122}$ Inhibition of invasion of bladder cancer cell lines with suramin was also demonstrated in a bladder tissue explant model. ${ }^{123}$ Although serious metabolic, hematologic, renal, and neurologic sequelae have been reported following systemic administration of suramin, its high molecular weight (1429 kDa) should prevent systemic absorption during intravesical administration. ${ }^{109}$ In an open-labeled, nonrandomized dose escalation Phase I trial, Ord et al administered six weekly intravesical doses of Suramin $(10-150 \mathrm{mg} / \mathrm{mL}$ in $60 \mathrm{~mL}$ saline) to 12 patients with a history of recurrent NMIBC. ${ }^{9,124}$ Findings demonstrate minimal evidence of local or systemic toxicity, and Phase II trials are currently in the preparatory phase. ${ }^{6}$

\section{Optimizing efficacy of current agents}

The unique properties of the bladder render it an ideal organ for regional therapy (Table 3). Access per urethra is noninvasive, and the urothelium provides a barrier preventing the systemic absorption of most small-molecule drugs. ${ }^{6,9}$ However, with topical therapies, cell kill is proportional to the duration of exposure and drug concentration rather than dosage. ${ }^{6,125}$ Current goals for improving the efficacy of intravesical therapy are maximizing tumor exposure to the therapeutic agent and limiting systemic exposure and host toxicity. ${ }^{6,9}$ Intravesical drug disposition is variable, and is affected by drug properties (molecular weight, and hydrophilicity, lipophilicity), urine volume and $\mathrm{pH}$, patient hydration status, and urothelial integrity. ${ }^{9,57}$

Drug concentration in the bladder is dependent on dose, volume of dosing solution, urine production, and the residual urine volume during instillation. ${ }^{6}$ Response rates with differing chemotherapeutic agents are variable, and several techniques have been employed to increase drug concentration and to enhance drug delivery. Completely emptying the bladder prior to drug administration, repositioning the catheter, or frequently changing patient position can help to avoid excessive residual urine volumes. ${ }^{9,126}$ In addition, patients should be encouraged to retain the instilled agent for as long as possible, with a two-hour urothelial contact time as an optimal goal. ${ }^{57}$

\section{Decreasing urine production}

\section{and urine alkalinization}

Optimization regimens have been established to maximize the effectiveness of MMC. A six-hour fasting period prior to instillation, reported to decrease urine volume and prevent $20 \%$ of drug dilution, is currently recommended in the European Association of Urology guidelines for NMIBC., ${ }^{9}, 127$ Cliff et al reported a $38 \%$ increase in intravesical MMC concentration following the administration of $0.2 \mathrm{mg}$ of oral desmopressin one hour prior to instillation; ${ }^{128}$ however, care must be taken in patients with cardiac failure or hyponatremia, and widespread use has not gained acceptance. ${ }^{6,9}$ Alkalinizing the urine with oral bicarbonate has also been shown to improve MMC drug stability, cellular uptake, and muscle penetration. ${ }^{57}$

Based on results from pharmacokinetic modeling that described drug disposition in urine and bladder tissues, the International Mitomycin C Consortium synthesized an optimized MMC treatment protocol that was tested in a multicenter, two-arm Phase III clinical trial. ${ }^{6}$ Patients in the optimized arm received a $40 \mathrm{mg}$ dose of $\mathrm{MMC}$ with pharmacologic manipulations to maximize drug delivery (ultrasound-guided bladder emptying, voluntary dehydration, and urine alkalinization with sodium bicarbonate) and patients in the standard arm received a $20 \mathrm{mg}$ dose in a $20 \mathrm{~mL}$ dosing volume without manipulations. ${ }^{6}$ Using a primary endpoint of time to recurrence and a secondary end point of recurrence-free rate, those in the optimized arm demonstrated a significantly increased median time to recurrence (29.1 versus 11.8 months, $P<0.001$ ) and a $19.1 \%$ increase in five-year recurrence-free rates..$^{9,126}$

\section{Increasing bladder wall penetration}

A number of novel chemical and physical approaches have been utilized in an effort to increase bladder wall penetration and enhance chemotherapeutic efficacy. ${ }^{69}$ It is important to note that while these techniques are promising, their efficacy in humans remains to be determined, and the findings presented need to be interpreted with caution. ${ }^{6,9}$ 
Table 3 Optimization of intravesical therapy for NMIBC

\begin{tabular}{|c|c|c|}
\hline Method & Mechanism & Side effects \\
\hline \multicolumn{3}{|l|}{ Permeation enhancers } \\
\hline DMSO & $\begin{array}{l}\text { Promotes urothelial penetration of water soluble } \\
\text { and lipophilic drugs }\end{array}$ & $\begin{array}{l}\text { Promotes systemic drug absorption } \\
\text { and urine production }\end{array}$ \\
\hline Chitosan & $\begin{array}{l}\text { Cationic polysaccharide rearranges cellular } \\
\text { junction and enhances paracellular drug transport }\end{array}$ & Promotes systemic absorption \\
\hline Polycarbophil & $\begin{array}{l}\text { Mucoadhesive polyacrylic acid cross-linked } \\
\text { with divinyl glycol chelates } \\
\text { extracellular calcium ions and opens } \\
\text { cellular tight junctions }\end{array}$ & Promotes systemic absorption \\
\hline Hyaluronidase & $\begin{array}{l}\text { Hydrolyzes hyaluronan in bladder mucosa } \\
\text { extracellular matrix; direct tumor suppression }\end{array}$ & $\begin{array}{l}\text { High concentrations may promote } \\
\text { tumor growth }\end{array}$ \\
\hline Electromotive therapy & Temporarily breaches bladder urothelium & Increased plasma absorption \\
\hline Hyperthermia & $\begin{array}{l}\text { Enhances DNA damage and inhibition of DNA } \\
\text { synthesis, alters intracellular drug trafficking and } \\
\text { distribution }\end{array}$ & Increased local irritation \\
\hline Photodynamic therapy & $\begin{array}{l}\text { Accumulation of a photosensitizing agent } \\
\text { facilitates selective tumor destruction following } \\
\text { exposure to light }\end{array}$ & $\begin{array}{l}\text { Skin hypersensitivity, detrusor } \\
\text { scarring and contracture }\end{array}$ \\
\hline \multicolumn{3}{|l|}{ Prolonging residence time } \\
\hline Bio-adhesive microspheres & $\begin{array}{l}\text { Sustained-retention delivery depots extend } \\
\text { drug exposure in the bladder cavity }\end{array}$ & Not yet evaluated in humans \\
\hline Magnetic targeting & $\begin{array}{l}\text { External magnets localize drug-containing } \\
\text { magnetic micro- and nano-particles in tumors }\end{array}$ & $\begin{array}{l}\text { Unknown; nonspecific localization } \\
\text { of magnetic particles }\end{array}$ \\
\hline Oral bicarbonate & $\begin{array}{l}\text { Urine alkalinization improves drug stability and } \\
\text { cellular uptake }\end{array}$ & Few \\
\hline
\end{tabular}

Chemical methods of increasing bladder wall permeability include use of dimethyl sulfoxide (DMSO), chitosan, polycarbophil, and hyaluronidase.$^{57}$ Initially utilized in the treatment of patients with interstitial cystitis, DMSO has been shown to induce and alter inflammatory tissue responses and neurotransmission. DMSO is a bipolar molecule that is highly miscible with water, lipids, and organic agents. ${ }^{6,9}$ Its ability to cross cellular membranes led to increased interest in the coadministration of DMSO with intravesical agents to promote the penetration of water- and lipidsoluble drugs. Initial efforts with cisplatin, doxorubicin, and paclitaxel showed promise. ${ }^{129}$ However, DMSO also resulted in increased urine production, as well as promoting systemic absorption of paclitaxel, ${ }^{129}$ which has dampened initial enthusiasm. Permeability enhancers that enhance drug transport by rearrangement of cellular tight junctions (chitosan, polycarbophil) or hydrolyzation of the bladder mucosal hyaluronan network (hyaluronidase) have also been investigated. ${ }^{9}$ In a porcine study, chitosan and polycarbophil were shown to increase bladder wall tissue penetration of pipemidic acid. ${ }^{130}$ Coadministration with hyaluronidase has been shown to reduce recurrence significantly in patients with NMIBC treated with MMC, without increasing systemic absorption. ${ }^{131}$
Physical methods to enhance permeability by urothelial disruption include hyperthermia, electromotive therapy, and photodynamic therapy ${ }^{6,9}$ Hyperthermia has been shown to enhance the efficacy of chemotherapeutic agents on inhibition of DNA synthesis and repair, increasing cell membrane permeability, and altering intracellular drug transport. ${ }^{109}$ Colombo et al evaluated the effectiveness of neoadjuvant local bladder hyperthermia in combination with MMC in 29 patients compared with 23 patients receiving MMC alone. ${ }^{6}$ All patients underwent TUR one week following therapy, and a pathologic complete response was observed in $66 \%$ versus $22 \%$ of patients, respectively $(P<0.01) .{ }^{132}$ This study was followed by a prospective, multicenter, randomized trial in which 42 patients with intermediate- and high-risk NMIBC received MMC in combination with local microwave-induced hyperthermia and 41 patients received MMC alone following TUR. ${ }^{9}$ With a minimum follow-up of 24 months, recurrence rates were significantly reduced in the combination therapy arm compared with the MMC alone arm $(17.1 \%$ versus $57.5 \%, P=0.002)$ respectively. ${ }^{133}$ The efficacy of local bladder hyperthermia in conjunction with intravesical chemotherapy has been confirmed in an additional single-arm series of patients with NMIBC. ${ }^{134}$ While these early results show exciting promise, trials comparing 
adjuvant microwave hyperthermia and MMC with single postoperative $\mathrm{MMC}$ instillation or adjuvant $\mathrm{BCG}$ are needed to define a true disease-recurrence benefit before it can be accepted as first-line therapy. ${ }^{6,9}$

Electromotive drug administration (EMDA), utilizing iontophoresis to create a potential difference across the bladder wall, has been shown to increase drug transport through biologic membranes and to enhance the effectiveness of intravesical agents when compared with passive administration alone. ${ }^{6,9}$ In a pilot study of 28 patients with high-risk NMIBC treated with EMDA-MMC versus MMC alone, complete response rates were equivalent, but a lower recurrence rate and disease-free interval were observed in the combination therapy arm. ${ }^{9,135}$ Di Stasi et al prospectively randomized 108 patients with high-risk NMIBC following TUR to EMDA-MMC, MMC alone, or BCG alone. Compared with MMC alone, the EMDA-MMC-treated arm showed a significant improvement in six-month recurrence-free rate (58\% versus $31 \%, P=0.01)$ and median time to recurrence (35 versus 19.5 months, $P=0.01$ ), and equivalent rates compared with the BCG treatment arm.,136 A subsequent trial randomized 212 patients with $\mathrm{T} 1 \mathrm{TCC}$ to $\mathrm{BCG}$ alone versus BCG followed by three cycles of EMDA/MMC. ${ }^{6}$ With a median follow-up of 88 months, patients treated with BCG followed by EMDA/MMC had lower recurrence rates $(41.9 \%$ versus $57.9 \%, P=0.001)$, and an increased disease-free interval (69 versus 21 months, $P=0.001$ ) when compared with BCG alone. ${ }^{137}$ Di Stasi et al recently presented data describing a new concept of preoperative recurrence prophylaxis with one single intravesical EMDA/MMC instillation immediately prior to TUR. In this prospective study, 167 patients with pTa G1-G2 bladder tumors were randomized to TUR alone, TUR + one single postoperative MMC instillation, or intravesical EMDA/MMC prior to TUR. With a median follow-up of 84.7 months, recurrence rates following preoperative EMDA/MMC (37\%) were superior to TUR alone (67\%), and MMC post-TUR (54\%, $P=0.007)$ which indicates that new therapeutic strategies may result in improved remission rates..$^{9,138}$

Photodynamic therapy (PDT) is emerging as an intriguing alternative treatment option. ${ }^{6}$ Based on the premise that accumulation of a photosensitizing agent in tumor cells may facilitate more selective destruction of malignant cells following exposure to light, early studies focused on porphyrin mixtures (Photofrin ${ }^{\circledR}$ ) and hematoporphyrin derivatives. ${ }^{9}$ Although response rates were encouraging, undesirable side effects including prolonged skin hypersensitivity and detrusor scarring and contracture discouraged its use. ${ }^{139}$ Subsequent trials of 5-aminolaevulinic acid (ALA), a precursor of the photosensitizer protoporphyrin IX, have shown that local and systemic (hypotension, tachycardia) toxicity could be avoided with intravesical administration. ${ }^{140}$ Berger et al administered 5-ALA $(50 \mathrm{~mL})$ in a $3 \%$ concentration intravesically in 31 patients with recurrent NMIBC (32\% BCG-refractory). With a mean follow-up of 23.7 months, treatment was well tolerated, and $48 \%$ of patients developed tumor recurrence. Due to the favorable side effect profile, the authors concluded that PDT could be applied safely in patients with recurrent bladder cancer who had failed BCG therapy or had comorbidities precluding more invasive surgical therapy. ${ }^{6,9,141}$ Current work to determine optimal ALA concentration and light energy required for effective ALA-PDT eradication is ongoing. ${ }^{140}$

\section{Prolonging residence time and site-directed targeting}

Prolonging bladder mucosal exposure to intravesically administered chemotherapy is a major challenge, due to agent insolubility in the aqueous form and immediate evacuation with voiding. ${ }^{6}$ Sustained-retention delivery platforms offer the promise of extending drug exposure in the bladder cavity beyond the voiding of urine. ${ }^{57}$ Bioadhesive microspheres and hydrogel systems have been tested in experimental models and have been shown to prolong bladder retention of agents, including paclitaxel ${ }^{120}$ and adriamycin, ${ }^{142}$ to promote urothelial absorption. ${ }^{9}$ Liposomes, positively-charged multilamellar lipid vesicles, have been utilized in animal models to enhance the intravesical delivery of hydrophobic agents such as capsaicin, ${ }^{143}$ currently being investigated in animal studies to facilitate intravesical drug delivery. ${ }^{6}$ Further studies are necessary prior to human trials, but sustained-retention delivery platforms show exciting potential in improving intravesical drug delivery. ${ }^{9}$

Magnetically-targeted carrier therapy utilizes a magnet placed externally on the skin covering a predetermined bladder site to localize drug containing magnetic particles in tumors and provide prolonged exposure to higher drug concentrations. ${ }^{6,9}$ Magnetically-targeted carriers are microparticles containing metallic iron to increase magnetic susceptibility and activated carbon to facilitate binding of the chemotherapeutic agent. In a porcine model, Leakakos et al demonstrated the feasibility of the intravesical administration of doxorubicin utilizing 300-800 mg magnetic particles. ${ }^{6}$ Plasma doxorubicin concentrations were below the level of detection, and histologic studies confirmed targeted 
microparticle localization in superficial and deep bladder tissue. ${ }^{144}$ While still in the initial investigatory period, this technology shows promise, particularly for bladder preserving protocols, and warrants further study. 6

\section{Early radical cystectomy}

There is increasing evidence that intravesical chemotherapy, while effectively reducing recurrence rates, does not show a disease-progression or survival benefit in patients with NMIBC. ${ }^{6}$ In addition, recent data has shown a disturbing trend towards decreasing disease-free survival rates in patients with $\mathrm{T} 1$ disease undergoing radical cystectomy following intravesical therapy. ${ }^{145}$ Of significant concern in these patients is the high prevalence of clinical understaging, ${ }^{7}$ which supports the consensus that the timing of radical cystectomy for high-grade NMIBC is critical to prognosis and long-term survival. ${ }^{6,9}$ Early cystectomy has been shown to result in better outcomes in patients with BCG-refractory T1 disease as well as CIS. ${ }^{33}$ Restaging TUR in patients with T1 disease is mandatory, ${ }^{7}$ especially in patients with evidence of disease recurrence. ${ }^{6}$ Furthermore, the case for performing early cystectomy in appropriate surgical candidates is strengthened by recent reports demonstrating improved perioperative morbidity and mortality rates, ${ }^{32}$ as well as improved patient satisfaction following orthotopic urinary diversions..$^{6,9,146}$ While intravesical therapy is an important component of the oncologist's armamentarium in the treatment of superficial bladder cancer, a radical cystectomy should be considered in all patients who have failed conservative management or who have T1 high-grade disease and tumor characteristics with high prognostic risk for recurrence. ${ }^{6,9}$

\section{Conclusion}

Bladder cancer is a prevalent disease with significant associated health care costs and social implications. The high rates of disease recurrence and progression and the need for lifetime surveillance impart a large financial and emotional burden on the health care system and patients diagnosed with bladder cancer. Following diagnosis, prompt repeat TUR represents the current standard of care to accurately stage patients and to identify patients who may benefit from early extirpative surgery. For patients with low volume Ta tumors, a single perioperative dose of intravesical chemotherapy is recommended by the AUA, and may provide a durable cure in many patients. The use of induction and maintenance BCG is recommended in patients with intermediate and high risk noninvasive disease, and may prevent disease recurrence and progression. For patients with muscle invasive disease, radical cystectomy remains the gold standard. Early radical cystectomy with continent diversion remains the gold standard for the treatment of muscle invasive disease, but may also improve quality of life and oncologic efficacy in patients with high grade T1 tumors with aggressive prognostic features, and should be considered as definitive first line thearpy.

For patients with NMIBC refractory to intravesical chemotherapy, radical cystectomy should be performed in appropriate surgical candidates. Unsuitable surgical candidates and BCG intolerant patients present a management dilemma. Reduction in BCG dosing limits local and systemic side effects and improves tolerability, but may compromise cancer control. Large meta-analyses have demonstrated the efficacy of chemotherapeutic agents including MMC, thiotepa, and doxorubicin as alternatives to BCG in preventing disease recurrence compared with TUR alone. ${ }^{6}$ Urine alkalinization, dehydration, and bladder emptying may improve the efficacy of currently available agents. Alternatively, photodynamic, gene, and electromotive therapies are emerging device-assisted technologies that may further optimize current treatments. Cytotoxic agents including gemcitabine, valrubicin, and BCG plus IFN as salvage therapy are currently under investigation, and have exhibited promising early efficacy. Apaziquone, taxoids, and suramin are the newest agents under investigation, but it will take several more years to compare their efficacy and superiority, if any, to current treatments. The ideal agent for the treatment of NMIBC remains unidentified, however a number of novel therapies appear promising, and we anticipate further significant advances concomitant with forthcoming discoveries.

\section{Disclosures}

The authors report no conflicts of interest in this work.

\section{References}

1. Ries L, Melbert D, Krapcho M, et al. SEER Cancer Statistics Review, 1975-2005. http://seer.cancer.gov/csr/1975_2005/.

2. Cancer Facts and Figures 2007. Atlanta: American Cancer Society; 2008

3. Fleshner NE, Herr HW, Stewart AK, Murphy GP, Mettlin C, Menck HR. The National Cancer Data Base report on bladder carcinoma. The American College of Surgeons Commission on Cancer and the American Cancer Society. Cancer. 1996 Oct 1;78(7):1505-1513.

4. Kurth KH, Bouffioux C, Sylvester R, van der Meijden AP, Oosterlinck W, Brausi M. Treatment of superficial bladder tumors: achievements and needs. The EORTC Genitourinary Group. Eur Urol. 2000;37 Suppl 3:1-9. 
5. Sylvester RJ, van der Meijden AP, Oosterlinck W, et al. Predicting recurrence and progression in individual patients with stage Ta T1 bladder cancer using EORTC risk tables: a combined analysis of 2596 patients from seven EORTC trials. Eur Urol. 2006 Mar;49(3): 466-465; discussion 475-467.

6. Smaldone MC, Gayed BA, Tomaszewski JJ, Gingrich JR. Strategies to enhance the efficacy of intravescical therapy for non-muscle invasive bladder cancer. Minerva Urol Nefrol. 2009 Jun;61(2):71-89.

7. Hall MC, Chang SS, Dalbagni G, et al. Guideline for the management of nonmuscle invasive bladder cancer (stages Ta, T1, and Tis): 2007 update. J Urol. 2007 Dec;178(6):2314-2330.

8. Avritscher EB, Cooksley CD, Grossman HB, et al. Clinical model of lifetime cost of treating bladder cancer and associated complications. Urology. 2006 Sep;68(3):549-553.

9. Smaldone MC, Casella DP, Welchons DR, Gingrich JR. Investigational therapies for non-muscle invasive bladder cancer. Expert Opin Investig Drugs. Mar;19(3):371-383.

10. Zaharoff DA, Hoffman BS, Hooper HB, et al. Intravesical immunotherapy of superficial bladder cancer with chitosan/interleukin-12. Cancer Res. 2009 Aug 1;69(15):6192-6199.

11. Den Otter W, Dobrowolski Z, Bugajski A, et al. Intravesical interleukin-2 in T1 papillary bladder carcinoma: regression of marker lesion in 8 of 10 patients. J Urol. 1998 Apr;159(4):1183-1186.

12. Weiss GR, O’Donnell MA, Loughlin K, Zonno K, Laliberte RJ, Sherman ML. Phase 1 study of the intravesical administration of recombinant human interleukin-12 in patients with recurrent superficial transitional cell carcinoma of the bladder. J Immunother. 2003 Jul-Aug;26(4):343-348.

13. Glazier DB, Bahnson RR, McLeod DG, von Roemeling RW, Messing EM, Ernstoff MS. Intravesical recombinant tumor necrosis factor in the treatment of superficial bladder cancer: an Eastern Cooperative Oncology Group study. J Urol. 1995 Jul;154(1):66-68.

14. Stravoravdi P, Toliou T, Kirtsis P, et al. A new approach in the management of urothelial tumors using GM-CSF on marker lesions: an ultrastructural and immunohistochemical study on the macrophage population in bladder mucosa. J Interferon Cytokine Res. 1999 Mar;19(3):221-225.

15. Zlotta AR, Van Vooren JP, Denis O, et al. What are the immunologically active components of bacille Calmette-Guerin in therapy of superficial bladder cancer? Int J Cancer. 2000 Sep 15;87(6):844-852.

16. Shelley MD, Court JB, Kynaston H, Wilt TJ, Fish RG, Mason M. Intravesical Bacillus Calmette-Guerin in Ta and T1 Bladder Cancer. Cochrane Database Syst Rev. 2000(4):CD001986.

17. Sylvester RJ, van der MA, Lamm DL. Intravesical bacillus CalmetteGuerin reduces the risk of progression in patients with superficial bladder cancer: a meta-analysis of the published results of randomized clinical trials. J Urol. 2002 Nov;168(5):1964-1970.

18. Badalament RA, Herr HW, Wong GY, et al. A prospective randomized trial of maintenance versus nonmaintenance intravesical bacillus Calmette-Guerin therapy of superficial bladder cancer. J Clin Oncol. 1987 Mar;5(3):441-449.

19. Lamm DL, Blumenstein BA, Crissman JD, et al. Maintenance bacillus Calmette-Guerin immunotherapy for recurrent TA, T1 and carcinoma in situ transitional cell carcinoma of the bladder: a randomized Southwest Oncology Group Study. J Urol. 2000 Apr;163(4):1124-1129.

20. Han RF, Pan JG. Can intravesical bacillus Calmette-Guerin reduce recurrence in patients with superficial bladder cancer? A meta-analysis of randomized trials. Urology. 2006 Jun;67(6):1216-1223.

21. Witjes JA. What is the optimal BCG dose in non-muscle-invasive bladder cancer? Eur Urol. 2007 Nov;52(5):1300-1302.

22. Rischmann P, Desgrandchamps F, Malavaud B, Chopin DK. BCG intravesical instillations: recommendations for side-effects management. Eur Urol. 2000;37 Suppl 1:33-36.
23. Sylvester RJ, van der Meijden AP, Oosterlinck W, Hoeltl W, Bono AV. The side effects of Bacillus Calmette-Guerin in the treatment of Ta $\mathrm{T} 1$ bladder cancer do not predict its efficacy: results from a European Organisation for Research and Treatment of Cancer GenitoUrinary Group Phase III Trial. Eur Urol. 2003 Oct;44(4):423-428.

24. Bohle A, Jocham D, Bock PR. Intravesical bacillus Calmette-Guerin versus mitomycin $\mathrm{C}$ for superficial bladder cancer: a formal metaanalysis of comparative studies on recurrence and toxicity. $J$ Urol. 2003 Jan;169(1):90-95.

25. van der Meijden AP, Sylvester RJ, Oosterlinck W, Hoeltl W, Bono AV. Maintenance Bacillus Calmette-Guerin for Ta T1 bladder tumors is not associated with increased toxicity: results from a European Organisation for Research and Treatment of Cancer Genito-Urinary Group Phase III Trial. Eur Urol. 2003 Oct;44(4):429-434.

26. Lebret T, Bohin D, Kassardjian Z, et al. Recurrence, progression and success in stage Ta grade 3 bladder tumors treated with low dose bacillus Calmette-Guerin instillations. J Urol. 2000 Jan;163(1):63-67.

27. Martinez-Pineiro JA, Martinez-Pineiro L, Solsona E, et al. Has a 3-fold decreased dose of bacillus Calmette-Guerin the same efficacy against recurrences and progression of $1 \mathrm{G} 3$ and Tis bladder tumors than the standard dose? Results of a prospective randomized trial. J Urol. 2005 Oct;174(4 Pt 1):1242-1247.

28. Shelley MD, Court JB, Kynaston H, Wilt TJ, Coles B, Mason M. Intravesical bacillus Calmette-Guerin versus mitomycin C for Ta and T1 bladder cancer. Cochrane Database Syst Rev. 2003(3):CD003231

29. Shelley MD, Wilt TJ, Court J, Coles B, Kynaston H, Mason MD. Intravesical bacillus Calmette-Guerin is superior to mitomycin $\mathrm{C}$ in reducing tumour recurrence in high-risk superficial bladder cancer: a meta-analysis of randomized trials. BJU Int. 2004 Mar;93(4):485-490.

30. Bohle A, Bock PR. Intravesical bacille Calmette-Guerin versus mitomycin $C$ in superficial bladder cancer: formal meta-analysis of comparative studies on tumor progression. Urology. 2004 Apr;63(4):682-686; discussion 686-687.

31. Sylvester RJ, van der Meijden AP, Witjes JA, Kurth K. Bacillus calmette-guerin versus chemotherapy for the intravesical treatment of patients with carcinoma in situ of the bladder: a meta-analysis of the published results of randomized clinical trials. J Urol. 2005 Jul;174(1):86-91; discussion 91-82.

32. Stein JP, Lieskovsky G, Cote R, et al. Radical cystectomy in the treatment of invasive bladder cancer: long-term results in 1,054 patients. J Clin Oncol. 2001 Feb 1;19(3):666-675.

33. Stein JP, Penson DF. The invasive T1 bladder tumor: contemporary issues and rationale for radical cystectomy. Curr Urol Rep. 2008 May;9(3):179-181.

34. Nepple KG, Aubert HA, Braasch MR, O'Donnell MA. Combination of BCG and interferon intravesical immunotherapy: an update. World J Urol. 2009 Jun;27(3):343-346.

35. Portillo J, Martin B, Hernandez R, et al. Results at 43 months' follow-up of a double-blind, randomized, prospective clinical trial using intravesical interferon alpha- $2 b$ in the prophylaxis of stage pT 1 transitional cell carcinoma of the bladder. Urology. 1997 Feb;49(2):187-190.

36. Braasch MR, Bohle A, O'Donnell MA. Risk-adapted use of intravesical immunotherapy. BJU Int. 2008 Nov;102(9 Pt B):1254-1264.

37. O'Donnell MA, Krohn J, DeWolf WC. Salvage intravesical therapy with interferon-alpha $2 \mathrm{~b}$ plus low dose bacillus Calmette-Guerin is effective in patients with superficial bladder cancer in whom bacillus Calmette-Guerin alone previously failed. J Urol. 2001 Oct;166(4):1300-1304, discussion 1304-1305.

38. Joudi FN, Smith BJ, O'Donnell MA. Final results from a national multicenter phase II trial of combination bacillus Calmette-Guerin plus interferon alpha-2B for reducing recurrence of superficial bladder cancer. Urol Oncol. 2006 Jul-Aug;24(4):344-348. 
39. Gallagher BL, Joudi FN, Maymi JL, O'Donnell MA. Impact of previous bacille Calmette-Guerin failure pattern on subsequent response to bacille Calmette-Guerin plus interferon intravesical therapy. Urology. 2008 Feb;71(2):297-301.

40. Lamm DL, O'Donnell MA. Multicenter randomized comparison of BCG with or without alfa $2 b$ interferon (IFN) and Oncovite (Onc) versus recommended daily allowance (RDA) vitamins during induction and extended 3-week maintenance. J Urol. 2008;179(4 suppl):584 (abstract no. 1705).

41. Witjes WP, Konig M, Boeminghaus FP, et al. Results of a European comparative randomized study comparing oral bropirimine versus intravesical BCG treatment in BCG-naive patients with carcinoma in situ of the urinary bladder. European Bropirimine Study Group. Eur Urol. 1999 Dec;36(6):576-581.

42. Sarosdy MF, Manyak MJ, Sagalowsky AI, et al. Oral bropirimine immunotherapy of bladder carcinoma in situ after prior intravesical bacille Calmette-Guerin. Urology. 1998 Feb;51(2):226-231.

43. Sarosdy MF, Tangen CM, Weiss GR, et al. A phase II clinical trial of oral bropirimine in combination with intravesical bacillus CalmetteGuerin for carcinoma in situ of the bladder: a Southwest Oncology Group Study. Urol Oncol. 2005 Nov-Dec;23(6):386-389.

44. Perabo FG, Muller SC. Current and new strategies in immunotherapy for superficial bladder cancer. Urology. 2004 Sep;64(3):409-421.

45. Jurincic-Winkler CD, Metz KA, Beuth J, Klippel KF. Keyhole limpet hemocyanin for carcinoma in situ of the bladder: a long-term follow-up study. Eur Urol. 2000;37 Suppl 3:45-49.

46. Lamm DL, Dehaven JI, Riggs DR. Keyhole limpet hemocyanin immunotherapy of bladder cancer: laboratory and clinical studies. Eur Urol. 2000;37 Suppl 3:41-44.

47. Flamm J, Donner G, Bucher A, Holtl W, Albrecht W, Havelec L. [Topical immunotherapy (KLH) vs chemotherapy (Ethoglucid) in prevention of recurrence of superficial bladder cancer. A prospective randomized study]. Urologe A. 1994 Mar;33(2):138-143.

48. Kalble T, Mohring K, Ikinger U, Riedasch G, Staehler G. [Intravesical prevention of recurrence of superficial urinary bladder cancer with BCG and KLH. A prospective randomized study]. Urologe A. 1991 Mar;30(2):118-121.

49. Morales A. Evolution of intravesical immunotherapy for bladder cancer: mycobacterial cell wall preparation as a promising agent. Expert Opin Investig Drugs. 2008 Jul;17(7):1067-1073.

50. Filion MC, Lepicier P, Morales A, Phillips NC. Mycobacterium phlei cell wall complex directly induces apoptosis in human bladder cancer cells. Br J Cancer. 1999 Jan;79(2):229-235.

51. Morales A, Chin JL, Ramsey EW. Mycobacterial cell wall extract for treatment of carcinoma in situ of the bladder. J Urol. 2001 Nov;166(5):1633-1637; discussion 1637-1638.

52. Morales A, Phadke K, Steinhoff G. Intravesical mycobacterial cell wall-DNA complex in the treatment of carcinoma in situ of the bladder after standard intravesical therapy has failed. J Urol. 2009 Mar;181(3):1040-1045.

53. Elsasser-Beile U, Ruhnau T, Freudenberg N, Wetterauer U, Mengs U. Antitumoral effect of recombinant mistletoe lectin on chemically induced urinary bladder carcinogenesis in a rat model. Cancer. 2001 Mar 1;91(5):998-1004.

54. Goebell PJ, Otto T, Suhr J, Rubben H. Evaluation of an unconventional treatment modality with mistletoe lectin to prevent recurrence of superficial bladder cancer: a randomized phase II trial. J Urol. 2002 Jul;168(1):72-75.

55. Elsasser-Beile U, Leiber C, Wolf P, Lucht M, Mengs U, Wetterauer U. Adjuvant intravesical treatment of superficial bladder cancer with a standardized mistletoe extract. J Urol. 2005 Jul;174(1):76-79.

56. Bochner BH. Gene therapy in bladder cancer. Curr Opin Urol. 2008 Sep;18(5):519-523.
57. Shen Z, Shen T, Wientjes MG, O'Donnell MA, Au JL. Intravesical treatments of bladder cancer: review. Pharm Res. 2008 Jul;25(7): $1500-1510$.

58. Sachs MD, Ramamurthy M, Poel H, et al. Histone deacetylase inhibitors upregulate expression of the coxsackie adenovirus receptor (CAR) preferentially in bladder cancer cells. Cancer Gene Ther. 2004 Jul;11(7):477-486.

59. Yamashita M, Rosser CJ, Zhou JH, et al. Syn3 provides high levels of intravesical adenoviral-mediated gene transfer for gene therapy of genetically altered urothelium and superficial bladder cancer. Cancer Gene Ther. 2002 Aug;9(8):687-691.

60. Connor RJ, Anderson JM, Machemer T, Maneval DC, Engler H. Sustained intravesical interferon protein exposure is achieved using an adenoviral-mediated gene delivery system: a study in rats evaluating dosing regimens. Urology. 2005 Jul;66(1):224-229.

61. Ramesh N, Ge Y, Ennist DL, et al. CG0070, a conditionally replicating granulocyte macrophage colony-stimulating factor--armed oncolytic adenovirus for the treatment of bladder cancer. Clin Cancer Res. 2006 Jan 1;12(1):305-313.

62. Fodor I, Timiryasova T, Denes B, Yoshida J, Ruckle H, Lilly M. Vaccinia virus mediated p53 gene therapy for bladder cancer in an orthotopic murine model. J Urol. 2005 Feb;173(2):604-609.

63. Lee CF, Chang SY, Hsieh DS, Yu DS. Immunotherapy for bladder cancer using recombinant bacillus Calmette-Guerin DNA vaccines and interleukin-12 DNA vaccine. $J$ Urol. 2004 Mar;171(3): $1343-1347$.

64. Horinaga M, Harsch KM, Fukuyama R, Heston W, Larchian W. Intravesical interleukin-12 gene therapy in an orthotopic bladder cancer model. Urology. 2005 Aug;66(2):461-466.

65. Gomella LG, Mastrangelo MJ, McCue PA, Maguire HJ, Mulholland SG, Lattime EC. Phase i study of intravesical vaccinia virus as a vector for gene therapy of bladder cancer. $J$ Urol. 2001 Oct;166(4): $1291-1295$

66. Kuball J, Wen SF, Leissner J, et al. Successful adenovirus-mediated wild-type $\mathrm{p} 53$ gene transfer in patients with bladder cancer by intravesical vector instillation. J Clin Oncol. 2002 Feb 15;20(4):957-965.

67. Pagliaro LC, Keyhani A, Williams D, et al. Repeated intravesical instillations of an adenoviral vector in patients with locally advanced bladder cancer: a phase I study of p53 gene therapy. $J$ Clin Oncol. 2003 Jun 15;21(12):2247-2253.

68. Pawinski A, Sylvester R, Kurth KH, et al. A combined analysis of European Organization for Research and Treatment of Cancer, and Medical Research Council randomized clinical trials for the prophylactic treatment of stage TaT1 bladder cancer. European Organization for Research and Treatment of Cancer Genitourinary Tract Cancer Cooperative Group and the Medical Research Council Working Party on Superficial Bladder Cancer. J Urol. 1996 Dec;156(6):1934-1940, discussion 1940-1931.

69. Lamm DL, Riggs DR, Traynelis CL, Nseyo UO. Apparent failure of current intravesical chemotherapy prophylaxis to influence the longterm course of superficial transitional cell carcinoma of the bladder. J Urol. 1995 May;153(5):1444-1450.

70. Huncharek M, Geschwind JF, Witherspoon B, McGarry R, Adcock D. Intravesical chemotherapy prophylaxis in primary superficial bladder cancer: a meta-analysis of 3703 patients from 11 randomized trials. J Clin Epidemiol. 2000 Jul;53(7):676-680.

71. Huncharek M, McGarry R, Kupelnick B. Impact of intravesical chemotherapy on recurrence rate of recurrent superficial transitional cell carcinoma of the bladder: results of a meta-analysis. Anticancer Res. 2001 Jan-Feb;21(1B):765-769.

72. Verweij J, Pinedo HM. Mitomycin C: mechanism of action, usefulness and limitations. Anticancer Drugs. 1990 Oct;1(1):5-13.

73. Mostafid AH, Rajkumar RG, Stewart AB, Singh R. Immediate administration of intravesical mitomycin $\mathrm{C}$ after tumour resection for superficial bladder cancer. BJU Int. 2006 Mar;97(3):509-512. 
74. Huland H, Otto U, Droese M, Kloppel G. Long-term mitomycin C instillation after transurethral resection of superficial bladder carcinoma: influence on recurrence, progression and survival. J Urol. 1984 Jul;132(1):27-29.

75. Allona Moncada A, Garcia Vaquero S, Zuloaga Gomez A, et al. [Preliminary results of a multicenter study with mitomycin C in superficial bladder tumors (Ta, T1)]. Actas Urol Esp. 1988 Sep-Oct;12(5):424-429.

76. Huland H, Otto U. Mitomycin instillation to prevent recurrence of superficial bladder carcinoma. Results of a controlled, prospective study in 58 patients. Eur Urol. 1983;9(2):84-86.

77. Tolley DA, Parmar MK, Grigor KM, et al. The effect of intravesical mitomycin $\mathrm{C}$ on recurrence of newly diagnosed superficial bladder cancer: a further report with 7 years of follow up. J Urol. 1996 Apr;155(4):1233-1238.

78. Oosterlinck W, Kurth KH, Schroder F, Bultinck J, Hammond B, Sylvester R. A prospective European Organization for Research and Treatment of Cancer Genitourinary Group randomized trial comparing transurethral resection followed by a single intravesical instillation of epirubicin or water in single stage Ta, T1 papillary carcinoma of the bladder. J Urol. 1993 Apr;149(4):749-752.

79. Bouffioux $\mathrm{C}$, Kurth $\mathrm{KH}$, Bono $\mathrm{A}$, et al. Intravesical adjuvant chemotherapy for superficial transitional cell bladder carcinoma: results of 2 European Organization for Research and Treatment of Cancer randomized trials with mitomycin $\mathrm{C}$ and doxorubicin comparing early versus delayed instillations and short-term versus long-term treatment. European Organization for Research and Treatment of Cancer Genitourinary Group. J Urol. 1995 Mar;153(3 Pt 2):934-941.

80. Sylvester RJ, Oosterlinck W, van der Meijden AP. A single immediate postoperative instillation of chemotherapy decreases the risk of recurrence in patients with stage Ta T1 bladder cancer: a meta-analysis of published results of randomized clinical trials. J Urol. 2004 Jun;171 (6 Pt 1):2186-2190, quiz 2435.

81. Ali-el-Dein B, Nabeeh A, el-Baz M, Shamaa S, Ashamallah A. Single-dose versus multiple instillations of epirubicin as prophylaxis for recurrence after transurethral resection of pTa and pT1 transitionalcell bladder tumours: a prospective, randomized controlled study. Br J Urol. 1997 May;79(5):731-735.

82. Koga H, Kuroiwa K, Yamaguchi A, Osada Y, Tsuneyoshi M, Naito S. A randomized controlled trial of short-term versus long-term prophylactic intravesical instillation chemotherapy for recurrence after transurethral resection of $\mathrm{Ta} / \mathrm{T} 1$ transitional cell carcinoma of the bladder. J Urol. 2004 Jan;171(1):153-157.

83. Friedrich MG, Pichlmeier U, Schwaibold H, Conrad S, Huland H. Long-term intravesical adjuvant chemotherapy further reduces recurrence rate compared with short-term intravesical chemotherapy and short-term therapy with Bacillus Calmette-Guerin (BCG) in patients with non-muscle-invasive bladder carcinoma. Eur Urol. 2007 Oct;52(4):1123-1129.

84. Koontz WW Jr, Prout GR Jr, Smith W, Frable WJ, Minnis JE. The use of intravesical thio-tepa in the management of non-invasive carcinoma of the bladder. J Urol. 1981 Mar;125(3):307-312.

85. Heney NM, Koontz WW, Barton B, et al. Intravesical thiotepa versus mitomycin $\mathrm{C}$ in patients with Ta, T1 and TIS transitional cell carcinoma of the bladder: a phase III prospective randomized study. J Urol. 1988 Dec;140(6):1390-1393.

86. Hirao Y, Okajima E, Ozono S, et al. A prospective randomized study of prophylaxis of tumor recurrence following transurethral resection of superficial bladder cancer--intravesical thio-TEPA versus oral UFT. Cancer Chemother Pharmacol. 1992;30 Suppl:S26-S30.

87. Martinez-Pineiro JA, Jimenez Leon J, Martinez-Pineiro L Jr, et al. Bacillus Calmette-Guerin versus doxorubicin versus thiotepa: a randomized prospective study in 202 patients with superficial bladder cancer. J Urol. 1990 Mar;143(3):502-506.

88. Burnand KG, Boyd PJ, Mayo ME, Shuttleworth KE, Lloyd-Davies RW. Single dose intravesical thiotepa as an adjuvant to cystodiathermy in the treatment of transitional cell bladder carcinoma. Br J Urol. 1976 Feb;48(1):55-59.
89. Byar D, Blackard C. Comparisons of placebo, pyridoxine, and topical thiotepa in preventing recurrence of stage I bladder cancer. Urology. 1977 Dec;10(6):556-561.

90. Zincke H, Utz DC, Taylor WF, Myers RP, Leary FJ. Influence of thiotepa and doxorubicin instillation at time of transurethral surgical treatment of bladder cancer on tumor recurrence: a prospective, randomized, double-blind, controlled trial. J Urol. 1983 Mar;129(3):505-509.

91. Prout GR Jr, Koontz WW Jr, Coombs LJ, Hawkins IR, Friedell GH. Long-term fate of 90 patients with superficial bladder cancer randomly assigned to receive or not to receive thiotepa. J Urol. 1983 Oct;130(4):677-680.

92. Stadler WM, Kuzel T, Roth B, Raghavan D, Dorr FA. Phase II study of single-agent gemcitabine in previously untreated patients with metastatic urothelial cancer. J Clin Oncol. 1997 Nov;15(11):3394-3398.

93. Dalbagni G, Russo P, Sheinfeld J, et al. Phase I trial of intravesical gemcitabine in bacillus Calmette-Guerin-refractory transitional-cell carcinoma of the bladder. J Clin Oncol. 2002 Aug 1;20(15):3193-3198.

94. Gontero P, Casetta G, Maso G, et al. Phase II study to investigate the ablative efficacy of intravesical administration of gemcitabine in intermediate-risk superficial bladder cancer (SBC). Eur Urol. 2004 Sep;46(3):339-343.

95. Bartoletti R, Cai T, Gacci M, et al. Intravesical gemcitabine therapy for superficial transitional cell carcinoma: results of a Phase II prospective multicenter study. Urology. 2005 Oct;66(4):726-731.

96. Mattioli F, Curotto A, Manfredi V, et al. Intravesical gemcitabine in superficial bladder cancer: a phase II safety, efficacy and pharmacokinetic study. Anticancer Res. 2005 May-Jun;25(3c):2493-2496.

97. Dalbagni G, Russo P, Bochner B, et al. Phase II trial of intravesical gemcitabine in bacille Calmette-Guerin-refractory transitional cell carcinoma of the bladder. J Clin Oncol. 2006 Jun 20;24(18):2729-2734.

98. Addeo R, Caraglia M, Bellini S, et al. Randomized Phase III Trial on Gemcitabine Versus Mytomicin in Recurrent Superficial Bladder Cancer: Evaluation of Efficacy and Tolerance. J Clin Oncol. 2009 Oct 19.

99. Perdona S, Di Lorenzo G, Cantiello F, et al. Is gemcitabine an option in BCG-refractory nonmuscle-invasive bladder cancer? A single-arm prospective trial. Anticancer Drugs. 2009 Oct 24.

100. Witjes JA, Hendricksen K. Intravesical pharmacotherapy for nonmuscle-invasive bladder cancer: a critical analysis of currently available drugs, treatment schedules, and long-term results. Eur Urol. 2008 Jan;53(1):45-52.

101. Patterson AL, Greenberg RE, Weems L, et al. Pilot study of the tolerability and toxicity of intravesical valrubicin immediately after transurethral resection of superficial bladder cancer. Urology. 2000 Aug 1;56(2):232-235.

102. Lamm DL, Blumenstein BA, Crawford ED, et al. A randomized trial of intravesical doxorubicin and immunotherapy with bacille CalmetteGuerin for transitional-cell carcinoma of the bladder. $N$ Engl J Med. 1991 Oct 24;325(17):1205-1209.

103. van der Meijden AP, Brausi M, Zambon V, Kirkels W, de Balincourt C, Sylvester R. Intravesical instillation of epirubicin, bacillus Calmette-Guerin and bacillus Calmette-Guerin plus isoniazid for intermediate and high risk $\mathrm{Ta}, \mathrm{T} 1$ papillary carcinoma of the bladder: a European Organization for Research and Treatment of Cancer genito-urinary group randomized phase III trial. J Urol. 2001 Aug;166(2):476-481.

104. Rajala P, Kaasinen E, Raitanen M, Liukkonen T, Rintala E. Perioperative single dose instillation of epirubicin or interferonalpha after transurethral resection for the prophylaxis of primary superficial bladder cancer recurrence: a prospective randomized multicenter study - FinnBladder III long-term results. J Urol. 2002 Sep;168(3):981-985.

105. Liu B, Wang Z, Chen B, et al. Randomized study of single instillation of epirubicin for superficial bladder carcinoma: long-term clinical outcomes. Cancer Invest. 2006 Mar;24(2):160-163. 
106. Duchek M, Johansson R, Jahnson S, et al. Bacillus Calmette-Guerin Is Superior to a Combination of Epirubicin and Interferon-alpha2b in the Intravesical Treatment of Patients with Stage T1 Urinary Bladder Cancer. A Prospective, Randomized, Nordic Study. Eur Urol. 2009 Oct 6.

107. Sekine H, Ohya K, Kojima SI, Igarashi K, Fukui I. Equivalent efficacy of mitomycin $\mathrm{C}$ plus doxorubicin instillation to bacillus CalmetteGuerin therapy for carcinoma in situ of the bladder. Int J Urol. 2001 Sep;8(9):483-486.

108. Steinberg G, Bahnson R, Brosman S, Middleton R, Wajsman Z, Wehle M. Efficacy and safety of valrubicin for the treatment of Bacillus Calmette-Guerin refractory carcinoma in situ of the bladder. The Valrubicin Study Group. J Urol. 2000 Mar;163(3):761-767.

109. Martin FM, Kamat AM. Definition and management of patients with bladder cancer who fail BCG therapy. Expert Rev Anticancer Ther. 2009 Jun;9(6):815-820.

110. Puri R, Palit V, Loadman PM, et al. Phase I/II pilot study of intravesical apaziquone (EO9) for superficial bladder cancer. J Urol. 2006 Oct;176(4 Pt 1):1344-1348.

111. Hendricksen K, Gleason D, Young JM, et al. Safety and side effects of immediate instillation of apaziquone following transurethral resection in patients with nonmuscle invasive bladder cancer. J Urol. 2008 Jul;180(1):116-120.

112. Jain A, Phillips RM, Scally AJ, Lenaz G, Beer M, Puri R. Response of multiple recurrent TaT1 bladder cancer to intravesical apaziquone (EO9): comparative analysis of tumor recurrence rates. Urology. 2009 May;73(5):1083-1086.

113. van der Heijden AG, Moonen PM, Cornel EB, et al. Phase II marker lesion study with intravesical instillation of apaziquone for superficial bladder cancer: toxicity and marker response. J Urol. 2006 Oct; 176(4 Pt 1):1349-1353; discussion 1353.

114. Hendricksen K, van der Heijden AG, Cornel EB, et al. Two-year follow-up of the phase II marker lesion study of intravesical apaziquone for patients with non-muscle invasive bladder cancer. World $J$ Urol. 2009 Jun;27(3):337-342.

115. Dimopoulos MA, Bakoyannis C, Georgoulias V, et al. Docetaxel and cisplatin combination chemotherapy in advanced carcinoma of the urothelium: a multicenter phase II study of the Hellenic Cooperative Oncology Group. Ann Oncol. 1999 Nov;10(11):1385-1388.

116. Rangel C, Niell H, Miller A, Cox C. Taxol and taxotere in bladder cancer: in vitro activity and urine stability. Cancer Chemother Pharmacol. 1994;33(6):460-464.

117. McKiernan JM, Masson P, Murphy AM, et al. Phase I trial of intravesical docetaxel in the management of superficial bladder cancer refractory to standard intravesical therapy. J Clin Oncol. 2006 Jul 1;24(19):3075-3080.

118. Laudano MA, Barlow LJ, Murphy AM, et al. Long-term Clinical Outcomes of a Phase I Trial of Intravesical Docetaxel in the Management of Non-Muscle-Invasive Bladder Cancer Refractory to Standard Intravesical Therapy. Urology. 2009 Nov 12

119. Barlow LJ, McKiernan JM, Benson MC. The novel use of intravesical docetaxel for the treatment of non-muscle invasive bladder cancer refractory to BCG therapy: a single institution experience. World J Urol. 2009 Jun;27(3):331-335.

120. Le Visage C, Rioux-Leclercq N, Haller M, Breton P, Malavaud B, Leong K. Efficacy of paclitaxel released from bio-adhesive polymer microspheres on model superficial bladder cancer. J Urol. 2004 Mar;171(3):1324-1329.

121. Crew JP, O’Brien T, Bradburn M, et al. Vascular endothelial growth factor is a predictor of relapse and stage progression in superficial bladder cancer. Cancer Res. 1997 Dec 1;57(23):5281-5285.

122. Gansler T, Vaghmar N, Olson JJ, Graham SD. Suramin inhibits growth factor binding and proliferation by urothelial carcinoma cell cultures. J Urol. 1992 Sep;148(3):910-914.

123. Fujiyama C, Jones A, Fuggle S, Bicknell R, Cranston D, Harris AL. Human bladder cancer invasion model using rat bladder in vitro and its use to test mechanisms and therapeutic inhibitors of invasion. Br J Cancer. 2001 Feb;84(4):558-564.
124. Ord JJ, Streeter E, Jones A, et al. Phase I trial of intravesical Suramin in recurrent superficial transitional cell bladder carcinoma. Br J Cancer. 2005 Jun 20;92(12):2140-2147.

125. Lamm DL. Intravesical therapy for superficial bladder cancer: slow but steady progress. J Clin Oncol. 2003 Dec 1;21(23):4259-4260.

126. Au JL, Badalament RA, Wientjes MG, et al. Methods to improve efficacy of intravesical mitomycin $\mathrm{C}$ : results of a randomized phase III trial. J Natl Cancer Inst. 2001 Apr 18;93(8):597-604.

127. Babjuk M, Oosterlinck W, Sylvester R, Kaasinen E, Bohle A, Palou-Redorta J. EAU Guidelines on Non-Muscle-Invasive Urothelial Carcinoma of the Bladder. Eur Urol. 2008 Aug;54(2):303-314.

128. Cliff AM, Heatherwick B, Scoble J, Parr NJ. The effect of fasting or desmopressin before treatment on the concentration of mitomycin $\mathrm{C}$ during intravesical administration. BJU Int. 2000 Oct;86(6):644-647.

129. Chen D, Song D, Wientjes MG, Au JL. Effect of dimethyl sulfoxide on bladder tissue penetration of intravesical paclitaxel. Clin Cancer Res. 2003 Jan;9(1):363-369.

130. Grabnar I, Bogataj M, Mrhar A. Influence of chitosan and polycarbophil on permeation of a model hydrophilic drug into the urinary bladder wall. Int J Pharm. 2003 Apr 30;256(1-2):167-173.

131. Hobarth K, Maier U, Marberger M. Topical chemoprophylaxis of superficial bladder cancer with mitomycin $\mathrm{C}$ and adjuvant hyaluronidase. Eur Urol. 1992;21(3):206-210.

132. Colombo R, Da Pozzo LF, Lev A, Freschi M, Gallus G, Rigatti P. Neoadjuvant combined microwave induced local hyperthermia and topical chemotherapy versus chemotherapy alone for superficial bladder cancer. J Urol. 1996 Apr;155(4):1227-1232.

133. Colombo R, Da Pozzo LF, Salonia A, et al. Multicentric study comparing intravesical chemotherapy alone and with local microwave hyperthermia for prophylaxis of recurrence of superficial transitional cell carcinoma. J Clin Oncol. 2003 Dec 1;21(23):4270-4276.

134. van der Heijden AG, Kiemeney LA, Gofrit ON, et al. Preliminary European results of local microwave hyperthermia and chemotherapy treatment in intermediate or high risk superficial transitional cell carcinoma of the bladder. Eur Urol. 2004 Jul;46(1):65-71; discussion 71-62.

135. Brausi M, Campo B, Pizzocaro G, et al. Intravesical electromotive administration of drugs for treatment of superficial bladder cancer: a comparative Phase II study. Urology. 1998 Mar;51(3):506-509.

136. Di Stasi SM, Giannantoni A, Stephen RL, et al. Intravesical electromotive mitomycin $\mathrm{C}$ versus passive transport mitomycin $\mathrm{C}$ for high risk superficial bladder cancer: a prospective randomized study. J Urol. 2003 Sep;170(3):777-782.

137. Di Stasi SM, Giannantoni A, Giurioli A, et al. Sequential BCG and electromotive mitomycin versus BCG alone for high-risk superficial bladder cancer: a randomised controlled trial. Lancet Oncol. 2006 Jan;7(1):43-51

138. Di Stasi SM, Storti L, Giurioli A, et al. Single immediate preoperative instillation of electromotive mitomycin-C plus transurethral resection versus transurethral resection alone versus transurethral resection plus immediate mitomycin-C for $\mathrm{pTa}$ bladder tumors: long term results of a prospective randomized trial. J Urol. 2008;179(suppl 4):585 (abstract \#1707).

139. Nseyo UO, DeHaven J, Dougherty TJ, et al. Photodynamic therapy (PDT) in the treatment of patients with resistant superficial bladder cancer: a long-term experience. J Clin Laser Med Surg. 1998 Feb;16(1):61-68.

140. Skyrme RJ, French AJ, Datta SN, Allman R, Mason MD, Matthews PN. A phase-1 study of sequential mitomycin $\mathrm{C}$ and 5-aminolaevulinic acid-mediated photodynamic therapy in recurrent superficial bladder carcinoma. BJU Int. 2005 Jun;95(9):1206-1210.

141. Berger AP, Steiner H, Stenzl A, Akkad T, Bartsch G, Holtl L. Photodynamic therapy with intravesical instillation of 5-aminolevulinic acid for patients with recurrent superficial bladder cancer: a single-center study. Urology. 2003 Feb;61(2):338-341.

142. Ye Z, Chen J, Zhang X, et al. Novel gelatin-adriamycin sustained drug release system for intravesical therapy of bladder cancer. J Tongji Med Univ. 2001;21(2):145-148. 
143. Tyagi P, Chancellor MB, Li Z, et al. Urodynamic and immunohistochemical evaluation of intravesical capsaicin delivery using thermosensitive hydrogel and liposomes. J Urol. 2004 Jan;171(1):483-489.

144. Leakakos T, Ji C, Lawson G, Peterson C, Goodwin S. Intravesical administration of doxorubicin to swine bladder using magnetically targeted carriers. Cancer Chemother Pharmacol. 2003 Jun;51(6):445-450.
145. Lambert EH, Pierorazio PM, Olsson CA, Benson MC, McKiernan JM, Poon S. The increasing use of intravesical therapies for stage T1 bladder cancer coincides with decreasing survival after cystectomy. BJU Int. $2007 \mathrm{Jul} ; 100(1): 33-36$.

146. Hautmann RE, Paiss T. Does the option of the ileal neobladder stimulate patient and physician decision toward earlier cystectomy? J Urol. 1998 Jun;159(6):1845-1850.

\section{Publish your work in this journal}

The Open Access Journal of Urology is an international, peer-reviewed, open access journal publishing original research, reports, editorials, reviews and commentaries on all aspects of adult and pediatric urology in the clinic and laboratory including the following topics: Pathology, pathophysiology of urological disease; Investigation and treatment of

\section{Dovepress}

urological disease; Pharmacology of drugs used for the treatment of urological disease. The manuscript management system is completely online and includes a very quick and fair peer-review system, which is all easy to use. Visit http://www.dovepress.com/testimonials.php to read real quotes from published authors.

Submit your manuscript here: http://www.dovepress.com/open-access-journal-of-urology-journal 